Working Paper

391

\title{
VISIBLE HAND: \\ PUBLIC POLICY AND ECONOMIC GROWTH IN THE NEHRU ERA
}

\author{
Pulapre Balakrishnan
}

November 2007 
Working Papers published since August 1997 (WP 279 onwards) can be downloaded from the Centre's website (www.cds.edu) 


\title{
VISIBLE HAND: \\ PUBLIC POLICY AND ECONOMIC GROWTH \\ IN THE NEHRU ERA
}

\author{
Pulapre Balakrishnan
}

November 2007

This paper is based on my research 'Understanding economic growth in India' being undertaken on a Senior Fellowship of the Nehru Memorial Museum and Library, New Delhi. I am indebted to the Foundation for enabling this research and encouraging its publication. Aditya Bhattacharjea, Bharat Ramaswami and M. Parameswaran generously commented on an earlier draft and provided vital suggestions for its reorganisation. I have benefited from discussions with G. Arunima, Amaresh Bagchi, V.N. and Ahilya Balasubramanyan, Amitava Bose, M.P. Chandrasekharan, Dayakar Bangara, Francine Frankel, Ajit Ghose, Jayati Ghosh, Ramachandra Guha, C.T. Kurien, N.J. Kurien, K.C. Mohan, Balaram Menon, Venugopal Menon, Dilip Mookherjee, Aditya Mukherjee, K.R.S. Murthy, R. Natarajan, Jayendra Nayak, Sushil Kumar Pillai, K. Pushpangadan, K.N. Raj, Murkoth Ramunny, Mahesh Rangarajan, Jairam Ramesh, M. Govinda Rao, S.K. Rao, Rammanohar Reddy, K. Saradamoni, C. Selvaraj, Arunava Sen, Parthasarathi Shome, AshokSoota, E. Sridharan,T.N. Srinivasan, Arvind Subramanian, M. Suresh Babu and Guilherme Vaz. I have also benefited from the comments of participants in seminars at the Nehru Library, Administrative Staff College of India at Hyderabad, Centre for Development Studies at Thiruvananthapuram and Centre for Policy Research at New Delhi. Finally, I gratefully acknowledge the role of K. Jayakumar, Mridula Mukherjee and N. Balakrishnan, administrators of the Nehru Library whose unstinting support alone has made this work possible. All responsibility is mine. 


\begin{abstract}
This paper investigates the relationship between the policy regime and growth during 1950-64 termed here 'the Nehru era'. While there exist valuable early appraisals of the period, access to new data and fresh information allows for a longer and comparative view of the outcome. We find overwhelming evidence not only of resurgent growth but also of a lasting transformation of a stagnant colonial enclave into an economy with firmer foundations capable of sustained growth. It is useful to recognise the economic policy of this period as distinct, not only from what preceded it but also from what came after, for that facilitates an understanding of the political conditions needed for economic interventions which are growth inducing. The paper also addresses some lingering perceptions of the economic policy of the time, notably its impact on agriculture and the governance of the public enterprises. The shibboleth 'Hindu rate of growth', presumably a broad-brush description of movement in this period, manages to obscure the extraordinary economic dynamics of the Nehru era.
\end{abstract}

Key words: Economic Policy in India, Nehru era, Drivers of Growth, Mahalanobis Strategy, Public Sector Performance

JEL Classification: O2, O3, O5, P5 
Every individual is “... led by an invisible hand to promote an end which was no part of his intention. By pursuing his own interest he frequently promotes that of the society more effectually than when he really intends to promote it."

Adam Smith: 'An Inquiry into the Wealth of Nations'

\section{Introduction}

It is a measure of the youthfulness of economics as a discipline that two centuries after the appearance of the 'Wealth of Nations', considered a landmark in its development, we are still asking the question 'How do economies grow?' ${ }^{1}$. While the awareness of such candid self-scrutiny may be flattering to a practitioner of the dismal science, it does speak of an unsettled issue at its core. This paper is a study of Indian economic growth for the one and a half decades from the middle of the twentieth century, a broad marker for the end of colonial rule. It is intended as a response of a kind to the challenge posed. As the period of the study coincides with Jawaharlal Nehru's leadership of India it would also serve as an evaluation of his role in the career of its economy. Though the latter can only be achieved here by implication it may yet be considered of some value as the best-known studies ${ }^{2}$ of Nehru treat his involvement in this space as of secondary importance. To anyone with a sense of the

1. See Scott (1997).

2. See, for example, Gopal $(1975,1979,1984)$. It is also the case with popular writing even when the verdict is altogether favourable, for which, see the tribute by Malhotra (2007). 
history of the time this must appear extraordinary. While neither a concern with economic growth in India nor a study of the Nehru era per se would require justification when taken on their own, their being considered jointly may be considered unusual today. My reason for doing so I now account for.

This narrative is being written at a time of some turbulence in the world of economic ideas, a turbulence that could hardly even have been anticipated about a decade ago. For the 1990s had appeared to be a final turning point with respect to ideas about economic growth, a turn that was largely driven by political events, the more far-reaching of which had been the crumbling of the Berlin Wall, itself symbolic of the differences between the two rivaling economic systems of the twentieth century. Certainly in the western world, a fierce competition had been unleashed for allegiance to one of either state-directedness or free markets as the organizing principle underlying economic arrangements for a society. The fact that to most intelligent observers this had always appeared to be a false dichotomy made little difference to how the end of the Cold War, following the implosion of the Soviet Union, was interpreted in the language of economic ideas. The triumphalism among those who had all along claimed the superiority of the market system said it all. To add to all of this, the world was also globalizing, which now meant markets on a global scale. In the immediate world of economic policy this had led to the purveying of a 'Washington Consensus'. This was a set of prescriptions on economic policy and were intended to serve as benchmark for the so-called 'emerging market' economies. The prefix itself merely referred to the fact that the US was now the sole super power and Washington, D.C. its capital. But 'consensus' was somewhat of a misnomer - as we were to discover later - for the reference was merely to the views held by the United States Treasury and the Bretton Woods institutions over which the former has always wielded some influence. All these, among the world's most powerful economic bodies, are based in Washington, D.C. Of course, the irony of it all was not lost 
on the author ${ }^{3}$ of the expression who had titled the article where it had appeared What Washington means by policy reform, implying that there was room for other interpretations. Williamson's original listing of the ingredients of a sound economic policy had contained: 1. Fiscal discipline, 2. Re-orientation of public expenditures, 3. Tax reform, 4. Financial liberalization, 5. Unified and competitive exchange rates, 6. Trade liberalization, 7. Openness to foreign direct investment, 8. Privatization, 9. Deregulation, 10. Secure property rights. Rodrik (2006) has, somewhat helpfully, summarised this to read: "Stabilise, Privatise, Liberalise"! While it may come across as somewhat of a caricature, it is certainly the case that this brief agenda had had wide purchase in the world of economic ideas in the middle of the nineteen nineties. In any case, it is clear that the so-called consensus did not think much of statedirectedness, holding that policy is to be guided by what is best for the free functioning of markets.

But it appears that a decade is a long time even in the sedate world of economic ideas. Just when the Washington Consensus had appeared to have settled in as the dominant framework, if not quite a paradigm, there is now a ferment again with regard to economic policy. This ferment in economic-policy (making) circles is well represented by the discussion centred on a relatively recent document ${ }^{4}$ of the World Bank titled 'Economic growth in the 1990s: Learning from a decade of reform'. In a review of this report Dani Rodrik has stated that “... it is a rather extraordinary document insofar as it shows how far we have come from the Washington Consensus. There are no confident assertions here of what works and what doesn't - and no blueprints for policymakers to adopt. The emphasis is in the need for humility, for selective and modest reforms, and for experimentation. "the central message of this volume," ..... the World Bank vice-president who oversaw the effort, writes in the

3. See Williamson (1990).

4. World Bank (2005). 
preface of the book, "is that there is no unique universal set of rules .... [W] need to get away from formulae and the search for 'best practices' ...". Occasionally, the reader has to remind himself that the book he is holding in his hands is not some radical manifesto, but a report prepared by the seat of orthodoxy in the universe of development policy." 5 Rodrik sees the Report as a marker in the evolution of thinking about the route to economic prosperity. He states that "Proponents and critics alike agree that the policies spawned by the Washington Consensus have not produced the desired results. The debate now is not over whether the Washington Consensus is dead or alive, but over what will replace it." ${ }^{3}$

Even as a leading economist, who has distinguished himself as a commentator on development policy, has pronounced on the state of the art many lines of investigation open up to us. However, I am firmly of the belief that while the time is ripe for thinking beyond the formulaic prescriptions of the Washington Consensus, development policy - at least for India where much has been attempted for close to half a century - must be at least partly guided by experience. It is from such a perspective that I revisit the relation between growth and the economic regime during the Nehru era of India's recent economic history. The choice is motivated by two considerations. The first is purely contextual in that it is guided by the discussion I have engaged in so far. As far as economic policy is concerned, nothing could be further from the spirit of the Washington Consensus than the public policy of the time. The state-directedness that had characterized it diverged sharply from the prescription that pride of place be given to the market. Moreover, the policy had unrelentingly targeted growth, so by focusing on this aspect a policy is being judged on its own terms. Secondly, the politics of the Nehru era had a certain integrity to it, the term being used here in a strictly descriptive sense. The distinctiveness to the politics of the period is that almost never since

5. Rodrik (2006), pp. 974-75.

6. Rodrik, ibid, p. 973. 
has the leadership of India been able to maintain as much autonomy from sectional interests. In this sense the economic policy regime had certain integrity at least in its conception, if not always in its implementation. Unlike later, when within the same overall framework of state directedness much of the intervention was merely rear-guard action to maintain ${ }^{7}$ the political power of a ruling dispensation.

Complementing my case for revisiting the experience of growth in the Indian economy of the Nehru era is a shard of evidence that comes from an altogether different debate from the one initiated by Rodrik. This is entirely empirical and altogether Indian in its boundaries of relevance, but it makes it no less striking in the context. Apparently finding excessive the focus on the last two decades of the twentieth century as the site for the sighting of the hand on the throttle, Hatekar and Dongre (2005) have cast their net wider, taking on the entire twentieth century when they search for a shift in the growth of GDP. It may come as surprise to some that the most significant break of the century is found to be in 1950. Now it becomes obvious to enquire what it is about mid-20th century India that marks it out as a watershed as far as economic growth in India is concerned. As we know that post-colonial economic policy had aimed to make a break from the immediate past, one is led naturally to look at public policy and economic growth in the Nehru era. This may be expected to serve two purposes. First, as it clearly marks a growth transition, we get an idea of what factors drive growth. Secondly, as it was also a period of high state-directedness, it enables us to assess how, if at all, such intervention can facilitate growth and how it can hold it back. The findings of such an exercise may be expected to have an audience beyond those interested in the recent history of India. To that extent it might indeed even end up contributing to the debate that Rodrik has flagged off.

7. See Hankla (2006) for an examination of subsequent Indian economic policy from such a perspective. 


\section{Imagining economic growth: The Nehru-Mahalanobis Strategy and its critics}

Though narrowly identified as the model for the Second Five-Year Plan, nothing is more iconic of the economics of the Nehru era and representative of the means adopted to pursue its goals than the Mahalanobis Model. The famed Model had first appeared in an essay ${ }^{8}$ on growth by the polymath. The model was intended to provide the analytical foundation for the project of raising the level of income via industrialisation already deliberated upon in the National Planning Committee of the Congress which was chaired by Nehru at the request of Subhash Chandra Bose in his capacity as the short-lived party president. For this reason it is often referred to as the Nehru-Mahalanobis Strategy ${ }^{9}$. This was a model to serve the end of rapidly raising the level of income through accelerating growth, as raising the level of income was considered the means to eliminating poverty.

Mahalanobis had conceived of an economy with two sectors, each producing capital and consumer goods, respectively. Being the model of a closed economy without government, their outputs would thus sumup to gross domestic product or national income.The capital good enter into the production of the consumer good and of itself. In an interesting departure from the economic theory of the time, capital was not subjected to diminishing returns. This implies that a greater initial allocation of investment to the production of capital goods would leave the economy with a higher stock of the same in the future. With these capital goods being the physical counterpart of investment, a higher initial allocation to capital goods production enables a higher investment in the future. Assuming that all thus feasible investment is undertaken, a higher level

8. See Mahalanobis (1955). Most of Mahalanobis's important writings on planning are contained in Mahalanobis (1960).

9. Two contrasting interpretations of it may be noted, the "synoptic view" of Chakravarty (1987) and the compleat deconstruction encompassing philosophy, mathematics and empirical detail, by Srinivasan (1996). 
of investment - in the context no more than 'putting (all of) the capital good to work' - is actualised. Now future-dated output is higher than what would have been the case were the initial allocation skewed more towards the production of consumer goods. Higher too would be the rate of growth of the economy in relation to the starting point. Now the planner's problem is to arrive at the share of investment to be allocated to the capital goods sector given the target level of income. I have here provided a bare-bones description of the Model and its logic. However, it is important when trying to understand the economic policy of the fifties to recognize that, even for its architect, the Model was meant only as a guide to a strategy for industrialisation. Therefore, it is equally important to understand ${ }^{10}$ the practical aspects of the strategy as manifested in what in the language of the day was referred to as 'the plan frame'.

At the heart of the Nehru-Mahalanobis Strategy was a fast growing 'heavy goods' sector. What are these heavy goods? They have been aptly described as "machine-building complexes with a large capacity for the manufacture of machinery to produce steel, chemicals, fertilizer, electricity, transport equipment, etc." 11 The means of bringing about a fast-growing heavy-goods sector was to invest disproportionately in these machine-building complexes. It was implicitly recognised that as the sector was characterised by long gestation lags in the production of output the rate of growth inherent in the Mahalanobis model would be lower in the short-run than that which would result from a strategy of investing disproportionately in consumer goods production. However, the longrun rate of growth resulting from the Mahalanobis strategy of shifting the investment allocation towards heavy goods would be a higher ${ }^{12}$, even for the consumer goods sector, as it enhances productive capacity

\footnotetext{
10. I am indebted to K. Narayanan Nair for this distinction.

11. Joshi (1979).

12. Demonstrated by Mahalanobis via simulation experiments.
} 
across the economy. In a sense the underlying idea of the Model is a kind of accounting. It estimates growth prospects based on current investment allocation, and chooses the allocation that maximizes the rate of growth for any given investment outlay. It is not entirely valuefree of course, in that it implicitly adopts a lower social rate of discount than could have been the case. It has been castigated as having been based on ideology ${ }^{13}$. This criticism begins to make sense only when one is told that the Model had been inspired by the Feldman model from the Soviet planning literature, even though Mahalanobis has stated ${ }^{14}$ that he was not aware of the work of Feldman at the time of formulation of his own model. Presumably, the criticism justifies itself by identifying any choice based on the Soviet experience as ideological. However, in the light of the quite spectacular expansion demonstrated by the Former Soviet Union of that time such a criticism would be ideological of itself, even though into the twenty-first century we were to have the hindsight to deduce that whatever was happening there was not sustainable. In the fifties, however, newly independent countries with ambition could hardly have been faulted for aspiring to what the Soviets had achieved, namely rapid industrialisation and the consequent increase in income within a remarkably quick time. It is not as if the entirely compromised politics of the Stalin regime, even without the gulag and the genocides, was overlooked. Only that Nehru was clear that India would avoid them at the cost of aiming at a lower rate of growth. It was clear that neither forced collectivisation as a route to raising the agricultural rate of growth or the suspension of democracy as a way of quelling dissent on the chosen strategy were even conceivable to the Indian leadership. So a relevant criticism of the strategy would only be of its economic logic and what it leaves out rather than of its provenance. Here the comment by Desai (2007) that Mahalanobis' model has in it no unemployment, inflation or

13. For example, see Price (1967), and the interchange between Vasudevan (1968) and Price (1968) that had followed.

14. See the passage reproduced in Chakravarty (1987). 
balance of payments is far more to the point. But once again, it is important to separate out the model from the strategy, and most of these except perhaps inflation were addressed by Mahalanobis in his writings on the Second Plan.

There was, however, a flaw in the model that is indeed related to where it had originated but this is far from having been constituted by ideology. As more or less an accounting scheme the Mahalanobis model was exclusively a supply-side model. There was no recognition of a possible demand constraint to capital accumulation and little scope for slackening demand growth to subvert the growth process. A model based on the purely physical relationship between inputs and outputs made sense in the Soviet Union, the classical 'command economy' where investment can be decreed by planners and enforced by commissars. Not so in India with a ubiquitous private sector that invests only in response to growing profits or its anticipation. Demand is now the lubricant. In the command economy the surplus could be constantly reinvested irrespective of market signals, thus maintaining a more or less constant growth dynamic, at least for some time. In the language of Growth Economics the savings are always invested, which since Keynes we recognise as a fiction at least for a market economy which India mostly was then. The only constraint to a seemingly endless growth in a command economy would be a declining investible surplus, which of course could also arise for entirely non-economic reasons such as political disaffection. Something of this sort perhaps describes the decline and fall of the Soviet economy after about five decades of rapid growth. However, even as late as the nineteen sixties there was no inkling of any impending collapse. But again, it is important to draw the distinction between model and plan as it were, and the plan did explicitly recognise the role of demand as I shall demonstrate below.

While the hubris that the state could direct investment indefinitely and at will within the economy appears to have carried away the planners 
of India, the criticism often encountered that they failed to recognise the importance of agriculture is merely ill-informed judgement. I intend to establish this. This is not so much as to rehabilitate the planners as much as to establish that they may not have succeeded as much as they would have liked, thus throwing some light on what should be done in India today. This indeed is the one of the uses of history for the economist. But before I turn to the role envisaged for agriculture within the NehruMahalanobis Strategy, I must consider what in the mind of some constituted a plan for an alternative development for India and a serious challenge to the Mahalanobis Plan. This was the plan presented by C.N. Vakil and P.R. Brahmananda of the Bombay School. The centre-piece of the Vakil-Brahmananda Plan was a 'wage-goods sector'. An entrée into what had gone on in the minds of these two economists is made when we appreciate the reason for their scepticism regarding the relevance of the Keynesian problematic ${ }^{15}$ for India. As recaptured by Brahmananda in an interview more recently ${ }^{16}$ Keynesian unemployment assumes 'excess capacity' including "stocks of wage goods and other circulating capital” while in India “. .. unemployment of labour exists because supply of labour wage goods to sustain labour as a cooperant factor with land and labour is inadequate." Note the self-consciously Classical terminology, for when Brahmananda is pressed to name the wage goods he chooses "corn and clothing". He had gone on to list fourteen items but we may rest with ‘foodgrains and textiles'. Essentially for Vakil and Brahmananda the multiplier mechanism cannot work in the absence of wage goods, and this led them to the proposition that employment cannot expand without wage goods. "So you see, for these reasons, agricultural development becomes fundamental. It has to be accorded priority independent of whatever you posit for industry." And again, an

15. Of course, this had already been queried by Rao (1952). Rao had been a graduate student at Cambridge immediately prior to the publication of the General Theory and is likely to have been au fait with its assumptions.

16. See 'Brahmananda' in Balasubramanyan (2001). 
observation quite relevant for India fifty years later, "The service and industry sectors cannot absorb more than a small proportion of the labour force. The service sector is (more?) important, but services can be expanded only with growing wage goods surpluses."17

So what is the proper appraisal of the Vakil-Brahmananda Plan? There can be no doubt that in focusing on unemployment they had honed in on a key reality of India in the nineteen fifties. Also, the centrality accorded to agriculture could not have been faulted. However, the authors of this plan appear to have underestimated the importance of capital goods for raising agricultural production. There is the suggestion ${ }^{18}$ that these could have been imported in return for the wage goods, but if wage goods were scarce enough to limit the expansion of employment in the first place it is not clear how easily a sufficient export surplus could have been generated. This question precedes any proclivity to 'export pessimism'. Next there is the question of competitiveness to be reckoned with. The much vaunted sterling balances had been built up during the War when India had supplied the Allied effort in a virtual seller's world market. These goods - being minor armaments, clothing and equipment - would no longer have been demanded to anything like the same extent after the War. As for the agricultural sector, the primary source of wage goods, it had been unable to supply even the domestic population adequately ${ }^{19}$ during the first fifty years of the twentieth century. This apart there was also the question of the very availability of capital goods to be purchased in the world market. This is convincingly argued by Chibber: "In the years after the war, capital goods in the form of plant and machinery were extremely scarce; not only did India not have any capital goods industry to speak of, but imports from the developed world were not on the near horizon, as European powers

17. All quotes are as reported in Balasubramanyan (2001). Question mark is mine.

18. See 'Brahmananda' in Balasubramanyan (2001).

19. Evidence on this is to follow. 
embarked on the reconstruction of their own economies and because the United States did not regard South Asia as a pivotal region. The problem with plant and machinery was mirrored by the problems with raw materials and intermediate goods, especially since, after partition, much of the Indian cotton and raw jute was now in Pakistan. In both these cases, businesses constantly called for the assistance of the state in securing the requisite import of goods." ${ }^{20}$ Far from being a tangential comment on the credibility of the Vakil-Brahmananda Plan, recognition of Indian export and import possibilities in the late forties is suggestive of the prospects for an Indian economic development through trade based on comparative advantage.

But the egregious absence in the wage-goods-led model is the economist's dues ex machine, the 'engine of growth'. Some of this is evident in Brahmananda's assertion that "If the system is expanding and you have a supply of food, people could stay in their homes and produce wage goods." 21 This agreeable picture begs the source of demand for the expansion in the macro economy. With hindsight, we can see that the Vakil-Brahmananda model was Classical more than just in its terminology, with employment determined in the labour market. There is no autonomous investment function, which would imply that the demand for labour as a derived demand gets determined in the goods market - independent of its price - and, in the context of their framework, independent of whether there is an adequate supply of wage goods. Of course, prices could still rise in the absence of wage goods and this would hold back the multiplier mechanism. However, as the unemployed are surviving as it is, it is possible to exaggerate 22 the degree to which the

20. Chibber (2003), p. 147.

21. From 'Brahmananda' in Balasubramanyan (2001).

22. See the response to Rao's paper by Raj (1954), and a conceptualisation of how macroeconomic equilibrium is restored when aggregate demand expands in an India-type economy by, the then remarkably young, Bhagwati (1956). 
expansion in output is curtailed following due to the expansion in aggregate demand.

It is possible to espy a strange symmetry between the Mahalanobis and the wage-goods models with the former downplaying the importance of capital goods and the later downplaying the importance of consumer goods! In fact, in the Mahalanobis two-sector model per se the absence of consumer goods cannot constrain output growth. However, once the overall Mahalanobis strategy is taken into account, we find that its oversight of a crucial ingredient for growth of the Indian economy namely consumer goods - is arguably less than that of what had been projected as a rival, the underestimation of the importance of capital goods by Vakil and Brahmananda. At least, Mahalanobis saw industrialisation as an input into agricultural growth and industrialisation was to be promoted by public investment. No serious scheme for transformation of the wage goods sector appears in the VakilBrahmananda Plan. But it is with respect to the crucial role of demand in the sustained expansion of an economy that the Mahalanobis Plan looks set to win us over. Explaining its logic even before the launching of the Second Plan in 1956, Mahalanobis had this to say: "The basic strategy is (now) clear. We create demand by a planned expansion of the basic industries and of the social sector, that is, health, education, etc. We meet the demand by a planned increase in the production of consumer goods as much as possible in the small and household industries, and the rest in factories. As both production and income increase, we divert a portion of the increase in income for new investments again in a planned manner to balance new demand by new production, and the process continues. At each stage, we must be careful that the right quantity of raw materials is available at the right time for production; and the right quantity of consumer goods is available at the right time to meet the demand." Of course, we can see the heroic assumptions of physical planning at work here - notably the question of planning without full control of prices in a private enterprise economy - but at least on the 
drawing board Mahalanobis' plan had hung together a little better than anything else that was on offer ${ }^{23}$ for India at that stage in history as it demonstrated an eye for the big picture. Finally, and as an aside, one might observe that critics of Indian economic policy in the fifties who saw the Mahalanobis Plan as violative of economic freedoms due to its reliance on controls ${ }^{24}$ are unlikely to have taken much comfort from the Vakil-Brahmananda Plan as its authors had placed it squarely in the field of planning. Indeed, once employment rather than output is targetted it is difficult to conceive of re-allocation of labour without envisaging forced migration, Brahmananda's vision of cottage industry notwithstanding. Direct force in shaping development was ruled out of court by Jawaharlal Nehru who held firmly to the belief that the only kind of economic progress worth having was 'progress by consent'.

Returning to the question of agriculture, not only was Mahalanobis acutely aware of its role in the scheme of things but he had incorporated this awareness into his strategy, if not so fully into his model. He had instantly recognised that in the nineteen fifties Indian agricultural growth was severely constrained by the availability of the most basic kind of industrial inputs. Thus agricultural growth was itself linked to industrialisation even though the extent could have been debated; that is, while brick and mortar was clearly essential, it is certainly not true that aircraft and automobiles were. Nevertheless the suggestion of a role for industrialisation in launching the transformation of Indian agriculture is not so entirely far-fetched. At this juncture I quote from the late Raj Krishna an economist who having placed himself at an obtuse angle visà-vis the establishment that had donned the Nehruvian mantle is unlikely to have ever been in thrall to it. Yet he has stated: "In a subcontinental

23. Desai (1998) has evaluated the Vakil-Brahmananda Plan as an alternative to the Mahalanobis. To be sure, there was also the Gandhian model of the self-sufficient village economy, but it had been explicitly rejected by Nehru himself, and stood no chance of being adopted by an almost entirely urban post-colonial leadership of India.

24. Notably Shenoy (1955). 
economy with a very large market, abundant natural resources of every kind, and vast reserves of unskilled and skilled manpower, the building up of a strong and diversified capital-goods base was a historical necessity. If today we can boast of a large measure of self-reliance, it is because considerable capacity has been created in the metallurgical, mechanical, chemical, power and transport sectors. These sectors are basic precisely because they are equally indispensable for defence, for large-scale consumer goods production, for small-industry development and rural development. The technical linkages between agriculture and industry are such that even a 4 percent rate of growth in agriculture is not possible without a high rate of growth in industries which supply the input requirements of a growing agriculture in the form of cement, bricks, pipes, pumps, electric power generation and transmission equipment, agricultural implements, diesel oil, fertiliser, pesticides, roads, vehicles, etc. And a seven percent growth in industry is not possible without a high rate of agricultural growth, because nearly half the modern industrial sector either processes agricultural output or supplies agricultural inputs." 25 Notice that the links conceived of between agriculture and industry in India at that early stage of development were both rudimentary and fundamental at the same time, and, for that very reason, recognition of it would have been central to any serious growth strategy. It would be difficult to credibly argue that the Nehru Mahalanobis Strategy had ignored, by design or by default, these links. To emphasise, I quote ${ }^{26}$ from the Second Five-Year Plan document: "It was appreciated that, in India, surplus is the key to industrialization. It is not only essential to grow enough food and fibres for our own requirements but it is also necessary to produce a surplus in the form of either industrial or food crops. In India agriculture and manufacturing industries are completely interlocked. Economic progress depends on the advance of both. Advance of one step in agriculture would supply food and raw materials for

25. Raj Krishna (1982), p. 59.

26. From Mahalanobis (1960), p. 96. 
advance of one step in manufacturing industries which again, in its turn, would speed up irrigation and increase the supply of fertilizers and pesticides and help in the promotion of scientific research, which would lead to further advances in agriculture."

While the raising of the level of income is widely recognised as the main objective of planning in the Nehru era Mahalanobis himself was additionally engaged with another one, a feature that is not widely known. This was to release India "permanently" 27 from the balance of payments constraint. Indeed, in his view this was the very logic of planning for industrialisation. This feature is seldom recognised, but it needs to be and when it is we are given an internal criterion, so to speak, by which to judge the economic policy of the Nehru era. After all, autonomy was at the core of the Nehruvian vision of economic development, not to mention of post-colonial India, and nothing would epitomise this more than a strong balance of payments position. Indeed, if an independent development was the objective this would never be achieved if India were strapped permanently to a balance of payments deficit. Having flagged this I return to the more recognisable objective of the economic policy of the time, namely the accelerated growth of income.

So a rapid increase in the level of income was the objective and this was to be brought about via greater investment in heavy industry. We have also seen that this was central to the plan for the transformation of Indian agriculture, a process that would require increased industrial inputs. But how was this to be resourced? The planners were fully aware that the step-up in investment envisaged in the Second Five-Year Plan was very substantial indeed. Indeed, in retrospect, they appear to have had a better sense of the role of resources in a credible economic plan than is found in the public discourse on growth today when the issue of

27. Mahalanobis (1960), p. 74. 
the 'policy regime' is given much too important a role. This is apparent from two elements of the plan to raise the level of income. First, no major foreign assistance was envisaged. This was in keeping with the idea of an independent development, a project incompatible with excessive reliance on foreign aid or, even, foreign direct investment. Taking the Second Plan as a case, foreign assistance was put down at less than 5 percent of total public expenditure in the proposed plan budget $^{28}$ for 1956-57 to $1960-61$ even as the investment rate was to be raised by over fifty percent from 7 to 11 percent of GDP. Of course, what the actual achievement with respect to foreign savings was we shall have occasion to study later. The second point to note is that the envisaged contribution of the public enterprises was significant, revealing the Indian state's understanding of their role in the economy. The item 'Additional Taxes and Loans \& Profits from State Enterprises' along with the "Contribution from the Railways' together equaled 'Loans from the Public' and were over twice what was to be taken as foreign assistance. I shall return to this central premise of public policy in the fifties that the public sector was expected to contribute resources to the larger project of national development.

Thus far I have been concerned with trying to establish what the leadership of the Nehru era had in mind as the ends and means. We have a reasonably good picture already but this gets crystallised when we read the speeches of Jawaharlal Nehru himself. Recall that Nehru was the Chairman of the Planning Commission and was closely involved with the planning process. These speeches would be of interest to us today not only in revealing the arduous process of deliberation by which policy was formed but point to the remarkable grasp that as an active career politician Nehru had on matters economic.

The first of these, made in 1952, gives us two insights into the economic calculations of the political leadership. It reveals that the idea

28. See Planning Commission (1956). 
of industrialisation as a goal to raise incomes was adopted even before the Mahalanobis model that had undergirded the Second Plan was written down. Further, it conveys the full recognition among the planners of the importance of agricultural growth to the industrialisation project. The extract follows: "There is much talk of industrialisation. In the initial chapters of the Plan, certain figures pertaining to the amounts allotted to industry, agriculture, social services, transport, etc., are given. In this respect, industry does not seem to occupy as important a place as agriculture. If I remember correctly, a very large sum is to be spent on irrigation. We certainly attach importance to industry, but in the present context we attach far greater importance to agriculture and food and matters pertaining to agriculture. If our agricultural foundation is not strong then the industry we seek to build will not have a strong basis either. Apart from that, the situation in the country today is such that if our food front cracks up, everything else will crack up, too. Therefore we dare not weaken our food front. If our agriculture becomes strongly entrenched, as we hope it will, then it will be relatively easy for us to progress more rapidly on the industrial front, whereas if we concentrate only on industrial development and leave agriculture in a weak condition we shall ultimately be weakening industry. That is why primary attention has been given to agriculture and food and that, I think, is essential in a country like India at the present moment." 29 This speech was made at a relatively early stage of the economic transformation that was being attempted. I now quote from two sets of speeches made almost at the end of Nehru's tenure as prime minister, indeed close to the end of his life. The first is really a politician's justification of the policies pursued by his government, and reads as such, but it does contain a clear understanding of the inter-temporal distribution of gains that was central to the economic strategy that was being pursued. It also reflects a certain understanding of the uniqueness of India, not in a civilisational sense

29 "Economic Democracy", speech made in Parliament on December 15, 1952, 'Jawaharlal Nehru's Speeches 1949-53', Publications Division, Ministry of Information and Broadcasting, GoI. 
but in the sense of the challenges it faces given its economic backwardness and its democratic polity. The extracts follow: "Planning has of course been done in other countries; but not through democratic processes. Other countries which are democratic have not accepted planning. But the combination of these two concepts is rather unique. .................. The first thing we realised was that it was no good copying America or Russia or any other country. The problems of India are her own. We can learn from America or Russia, as certainly we should. But the economic problems of India are different. We learn from them, of course, as they have acquired great experience. We always realised that the fundamental factor was growth in agricultural production. Agriculture is basic to us because however much importance we attach to industry unless we have surplus from agriculture, we cannot progress in our economy. We cannot live on doles from other countries. We have always to choose between benefits accruing today, or tomorrow, or the day after. From the country's point of view, if we spend the money we now have for some petty immediate benefits, there will not be any permanent benefit. One has to find a healthy balance between the immediate benefits of today and the long-range benefits of tomorrow. All the money we have put in heavy industries is for tomorrow's benefit, though it brings in some benefit today also. It will take some years before this investment yields fruits. ...... So, our strategy of economic development is essentially modernisation of agriculture and training of our rural masses in the use of new tools and new methods. At the same time, it seeks to lay the foundations of an industrial structure by building the basic or heavy industries, above all by producing electric power. Middle and small scale industries will inevitably come in their train." 30 A clearer articulation of the central issues in investment planning, namely the choice of the longgovernment, Lok Sabha, August 22, 1963, reprinted in 'Jawaharlal Nehru's Speeches 1963-64', Publications Division, Ministry of Information and Broadcasting, GoI. 
run output-maximizing allocation of investment across activities would be hard to find. The second set of speeches that I had referred to show us a Nehru somewhat despondent regarding the extent of progress made on the agricultural front. He even suggests that agriculture has been neglected relative to its importance. The first extract is from a speech made to the Chief Ministers at the annual meeting of the National Development Council in 1963. It goes: "Emergency was declared in the wake of Chinese invasion. ... Emergency does not merely mean raising soldiers or getting aircraft. It means production, production for defence specially. All other types of production, more particularly on the agricultural front, is equally necessary. ... We have done many things which are creditable to us. But the overall picture is not one of fast progress, specially in the agricultural domain. This is rather distressing because agriculture is the basis of all our development work. If we fail in agriculture, it does not matter what else we achieve - how many plants we put up - our economic development will not be complete. ..... Agriculture is more important than industry for the simple reason that industry depends on agriculture. Industry, which is, no doubt, very important, will not progress unless agriculture is sound and stable and progressive. I find there is a passion in many areas of India for industrial plants. Well, all good luck to those who want them. Let them have it. People seem to think that an industrial plant solves all the problems of poverty, which it does not. It has a longterm effect on the economy, no doubt. And I have no doubt in my mind that the problem of poverty will not be solved in India except through industrial progress, industrial progress of the latest type. That is the truth. However, at the present moment, whichever way you start in India, you come back to agriculture. We dare not be slack about it, as we have been, I'm afraid, in many places." 31 The final extract that I wish to quote is from a speech delivered less than six months before Nehru's death. It

31 "Agriculture - Basis of Economic Development", speech made to the National Development Council, New Delhi, November 8, 1963, reprinted in 'Jawaharlal Nehru's Speeches 1963-64', Publications Division, Ministry of Information and Broadcasting, GoI. 
goes: "Though we all know that agriculture is essential and basic, it has been rather neglected. I say neglected in the sense that people hoped that crops will grow by themselves and not by much effort on our part. Now, greater attention is being paid to it and I hope this will bear results. There are all manner of things that go into agriculture. We have large irrigation schemes, but it takes a long time for us to take advantage of them fully. We first, spent a lot of money and energy in building them. Between the two there has been a long gap. We should plan for their full utilisation in advance." 32

As is often the case, political leaders are too close in time to historical events to be able to evaluate them dispassionately. In retrospect, Nehru was to prove himself unduly pessimistic! A growth transition in agriculture was to come within years of this speech made to India's chief ministers at the annual meeting of the National Development Council in December 1963, on which occasion Nehru had had the gall to also pronounce that " ... agriculture is more important by itself than any chief minister". An acceleration in the agricultural growth rate was to take place in the mid-sixties probably ${ }^{33}$ even in 1964-65, the year of his death. Though he did not live to see its beneficial effects spread cross the Indian economy by stimulating other sectors, there can be very little doubt, as I demonstrate later, that this transition has much to do with the policies implemented by his government. At another level it would be difficult for a citizen in the twenty first century to encounter a member

32 "Irrigation and Power", speech to the Conference of Ministers of Irrigation and Power, New Delhi, January 3 , 1964, reprinted in 'Jawaharlal Nehru's Speeches 1963-64', Publications Division, Ministry of Information and Broadcasting, GoI.

See Balakrishnan and Parameswaran (2007). However, while the point estimate for the date of acceleration is 1965-66, the estimate itself comes with confidence intervals that allow for an acceleration to have taken place anywhere between 1964 and 1966, inclusive. But precise dating is not so essential here, as I shall argue below. In any case, the rate of growth registered in 1964-65, the year of Nehru's death, was at close to 12 percent the highest annual production increase in crop agriculture in a decade and a half. See 'Agricultural Statistics at a Glance', New Delhi: Ministry of Agriculture, Government of India, 2003. 
of the political class as self-critical as we find Nehru in the passages that I have quoted from above. Across the world's democracies today, introspection would not be considered a virtue of political practice. I now turn to economic growth in the India of the Nehru era.

\section{The recovery of India: Economic growth in the Nehru era}

We may use two sets of comparators to evaluate the growth performance of an economy. One is the record of preceding growth in that economy itself. The other is the contemporaneous growth of other economies similarly placed and the growth of leading economies at early stages of their own growth. We start therefore with a comparison of growth in the Nehru era with growth in the first half of the twentieth century, more precisely the period 1900-47 which marks the second half of the British Raj in India.

In Table 1 are arrayed growth rates over time of the three main sectors of the Indian economy. The layout of the Table enables us to see the economic performance of the Nehru era in century-wide perspective.

Table 1: The trend growth rate of GDP (1948-49 prices)

\begin{tabular}{|l|c|c|c|}
\hline Sector & $\begin{array}{c}1900-1 \text { to } \\
1946-47\end{array}$ & $\begin{array}{c}1947-8 \text { to } \\
1999-2000\end{array}$ & $\begin{array}{c}1950-1 \text { to } \\
1964-5\end{array}$ \\
\hline Primary & 0.4 & 2.5 & 2.6 \\
\hline Secondary & 1.5 & 5.5 & 6.8 \\
\hline Tertiary & 1.7 & 5.0 & 4.5 \\
\hline GDP & 0.9 & 4.1 & 4.0 \\
\hline GDP per capita & 0.1 & 1.9 & 1.9 \\
\hline Population & 0.8 & 2.0 & 2.0 \\
\hline
\end{tabular}

Notes: Data are annual average compound growth rates. Pre-1947 data are for 'Undivided India' which entity includes the Indian states and Pakistan but excludes Burma. Source: Sivasubramonian (2005). 
In column 1 are the data for the years 1900-47. In column 2 are the data on the same indicators for the rest of the twentieth century including the 17 years of Jawaharlal Nehru's prime ministership. In column 3 are presented the same indicators for the period 1950 to 1964, the year of Nehru's death. Read together the data convey two important points. First, not only does growth in the Nehru years amply exceed what was attained in the final half-century of colonial rule, but the quickening of the economy observed in the second half of the twentieth century may be seen to have been already achieved ${ }^{34}$ in the Nehru era. Secondly, not only is there an acceleration of growth across all sectors but also the ranking of sectors by growth is reversed early with the commodityproducing sectors now growing faster than services which had been the fastest growing segment of the colonial economy. Following Kuznets's work on economic growth, high services growth in a low-income economy would be treated as pathologicaly. In a poor economy with a low level of consumption of even the most basic goods, a faster growth of the commodity sectors is a desirable outcome. The broad-based expansion of the economy during the Nehru era amounts to a transformation of the economy is, perhaps, more likely to readily recognised as such by economic historians. To stretch my argument a bit, I refer ${ }^{35}$ to a debate among economic historians on the true significance of the Industrial Revolution agreed by them to have taken place in Europe in the middle of the eighteenth century. In this connection Joel Mokyr, a historian of technology, has observed that growth after the Industrial Revolution was not just higher but qualitatively different in at least three different respects from what had gone before. First, growth ceased to be a "niche phenomenon". Before 1750, it had been limited to relatively small areas or specific sectors. Second, while pre-1750 growth

34. Of course, finer partitions of the data points over 1950-2000 would yield a higher rate of growth from the late seventies. However, it is the case that the acceleration during the Nehru years outweighs by far the ones that followed, for which see Parameswaran (2007).

35. I thank M. Suresh Babu for having drawn my attention to this literature. 
had seen "institutional change in the widest sense", technological change though not absent was far too slow and localised compared to the role it was to play afterwards. Third, 'pre-modern' growth was vulnerable to setbacks and shocks both man-made and natural that made doubtful its sustainability. While it may not be entirely appropriate to transfer this description to the transformation of India during the Nehru era, as a certain amount of modern industry was in place by 1947, the parallels are there to see. Though not all three of Mokyr's observations are evident from the data I have presented in Table 1, it would be agreed upon that the Nehru years witnessed widespread growth across the economy, a technological advance was fostered, and we now see that the growth in income has not only been sustained for over fifty years but the growth rate itself has actually been 'hastening slowly' ${ }^{36}$. However, two of Mokyr's comments on the significance of the Industrial Revolution appear to have been tailor-made for the period that we are studying here. First, in response to the observation that the growth achieved in the early stage of the Revolution was not that much, he has responded that the change must not be seen as one of mere degree: "There is a qualitative difference between an economy in which GDP per capita grows at 1.5 percent and one in which it grows at 0.2 percent." 37 While the parallel here between the data for the period Mokyr speaks of and India for our period is, as is evident from Table 1, close indeed, it is Mokyr's more general comment on the significance of the Industrial Revolution that is, in my view, of greater import. His evaluation is that: "It may have been slow, it may have been not all that industrial and even less revolutionary, it may not even have been wholly British, but it was the taproot of modern economic growth." ${ }^{38}$ To seek parallels between the growth following the Industrial

36. The accelerations in the growth of GDP during the second half of the twentieth century have been statistically established by Balakrishnan and Parameswaran (2007).

37. Mokyr (2005), p. 286.

38. ibid., p. 286. 
Revolution in Britain and the growth of India during the Nehru era is a promising line of inquiry for a historian of the Indian economy. On the other hand, I shall now put to use Mokyr's characterisation of the Industrial Revolution not to draw a parallel but to highlight a difference between the two periods under comparison here. While growth in the Nehru era was distinctly Indian, in that it was not dependent on either foreign trade or foreign aid, it certainly was "not all that industrial". Indeed the greatest expansion of the economy in the Nehru years is not in industry at all. While the categories for which growth is recorded in Table 1 are somewhat broad, the data reveal that growth acceleration in the Primary sector, largely comprising agriculture, had exceeded that of the Secondary sector, more or less synonymous with industry. This has generally gone unrecognised, and I shall return to consider at length both the approach to agriculture and the record of its performance in these years. But for now it is worth repeating Sivasubramonian's apposite assessment of the economic achievement of this period. He speaks of the economic recovery of the Nehru era as having been "swift, smooth and remarkable." 39 Before moving on I might raise a point crucial to the comparison of growth over time. As the comparison has to be made at constant prices to be of any value, the choice of the base year for prices is crucial. I have used Sivasubramonian's estimates of GDP as they provide data at constant prices for the entire twentieth century. There are of course alternative estimates for the period 1900-47 and these give way to a very different insight into the period. For instance, Angus Maddison's estimates ${ }^{40}$ of GDP growth in 1938-9 prices for this period show the average annual growth rate of per capita output during this period almost stagnant at 0.04 percent per annum. This estimate would

39. Sivasubramonian (2005), p. 563. This is noticeably at odds with the customary assessment of the economic record of the Nehru era by economists. Historians, it appears, bring a greater objectivity to the study of the economy than economists as they tend to privilege economic theory less.

40. Reported by Sivasubramonian (2005), Table 6.3. 
Table 2: Economic growth in India compared

\begin{tabular}{|l|c|c|}
\hline & $1950-64$ & $1820-1992$ \\
\hline India & 4.1 & - \\
\hline China & 2.9 & - \\
\hline Korea & 6.1 & - \\
\hline United States & - & 3.6 \\
\hline United Kingdom & - & 1.9 \\
\hline Japan & - & 2.8 \\
\hline
\end{tabular}

Notes: Data are annual average growth rates. Source: Maddison (1995).

suggest a far more significant turnaround following the end of the colonial era. I now turn to the second of the two standard comparators of the growth performance of an economy, the performance of other economies. Two sets of economies have been chosen here for comparison with India during the Nehru era. The first is a set of Asian economies. These were more or less on par with India in terms of per capita income in 1950. The second is a set of the world's best-performing economies of all time. In Table 2 are presented growth rates attained by these two. Of the two sets of economies for which data are presented a comparison of India's performance with that of the Asian economies is of greater interest for two reasons. First, the data are for the same period and secondly, as stated, in terms of per-capita income Korea and China had economies that were more or less on par with India in 1950. A noteworthy finding emerges. From the work of De Long ${ }^{41}$ we know that though India has grown faster than most of Africa during the last five decades it has performed worse than East Asia. If Korea is taken as synonymous with East Asia this feature holds also for the period 1950-64. Korea's growth rate is 50 percent higher than India's for this period. However, we find that India's growth rate is 25 percent higher than that of China. This is

41. DeLong (2004). 
little known but is not entirely surprising. Actually, China was to pull ahead of India only a decade and a half beyond the Nehru era, in the late seventies and following the reforms unleashed by Deng Xiao Ping. Possessed of this information we are led to speculate that admiration for Mao in India during his lifetime must have been based on grounds other than mere economic achievements. This is clear, for the revelations of the disastrous consequences of the Great Leap Forward - including an estimated thirty million deaths allegedly due to famine in the late fifties - were received sanguinely here in India. While this may well be expected of the ideologically committed, one thing is clear from our comparison. In a comparison with China it now appears that Nehru had not left the Indian at any great disadvantage. The subsequent tearing away of China, and the falling behind of India in the growth-league tables, owes itself to causes other than his leadership.

No less revealing is a comparison of the growth in India during 1950-64 with long term growth in the leading OECD economies. We find from Table 2 that the former had exceeded the latter, often substantially. It is now possible to place in perspective Raj Krishna's lament ${ }^{42}$ that independent India's record of growth till the late seventies placed it lower than one hundred economies world-wide. Krishna had used per capita GDP as his measure. This succeeds in masking the degree of progress made in the Nehru era. An altogether unexpected consequence of the transformation of the economy had been a very significant rise ${ }^{43}$ in the rate of growth of population. Now the measured rate of growth of per capita GDP is lowered. Two observations are in order here. From Table 1 we can see that were the rate of growth of population to remain at the colonial rate the rate of growth of per capita income during 195064 would have exceeded 3 percent. This is more than twice ${ }^{44}$ the rate of

\footnotetext{
42. See Krishna (1982).

43. See Table 1.

44. See Maddison (1995).
} 
growth of per capita income of US and UK during 1820-1992, and exceeds that attained by Japan during the same period. Before I move on to my second observation I might remark that, actually, the counterfactual considered is quite absurd as the growth of population is very likely endogenous with respect to the growth of income. This leads me to the observation itself. The rise in the rate of growth of population per se serves as an indicator far more vivid of the extent and nature of the economic transformation than any estimated rise in the rate of growth. Life expectancy at birth rose from 32 years in the 1940s to 37 years in the 1950 s and to 43 years in the $60 \mathrm{~s}^{45}$ Demographers ${ }^{46}$ have put the rise in the rate of growth of population in the period that we are studying down to the increase in the fertility rate, itself due to the decline in the incidence of malaria and widowhood, presumably due to improving public health outreach.

A methodological point needs to be made here that is more than a mere justification for the method that I have pursued. Note that in Table 2 I have compared growth in India during the Nehru years with very long term growth of the advanced OECD economies. Far from loading the comparison in favour of the former, as it may appear, this actually tilts the balance in the direction of the latter. For we know that long-term growth of the industrialised economies has accelerated ${ }^{47}$ over the last couple of centuries. Therefore the longer the time period we consider the greater the likelihood of observing a higher growth rate for these economies when compared with a shorter series commencing from a time when their per capita income was the same as that of India's in, say, 1950. This observation has, in addition, the virtue of placing in perspective the achievement of the Nehru era. In the presence of increasing returns

45. Bhat (2001).

46. ibid.

47. See Romer (1986). 
to scale the observed growth cannot be dismissed ${ }^{48}$ merely as the arithmetic consequence of measuring a given increase against a 'low base'. That would at best be a statistical commentary. It misses that from an economic standpoint, initiating growth in the presence of increasing returns to scale, a low base is actually a serious impediment to growth, for the lower the scale of production the lower, proportionately, is the surplus available for investment. Thus high growth on a low base is nontrivial; and the recognition as a substantial achievement its initiation in the nineteen fifties - after half a century of stagnation - the compelling conclusion. Interestingly, at the time, Nehru himself had demonstrated a clear idea of the magnitudes involved in the task of raising the rate of growth: "We have aimed at 5 percent in this Plan, and five percent is going to be a hard job. We shall have to work very hard, because we have started at such low levels, with such low surpluses. India is almost at the lowest rung of the income ladder. Even China, I believe, is a little higher. So was Russia at the time of the Revolution." 49 The challenge had been sharply appraised.

\section{Movement along a broad front: What quickened India?}

As is evident from the discussion in the previous section there can be no debate over the fact of the dramatic quickening of the Indian economy since the initiation of planned economic development in the second half of the twentieth century. To quote a prominent economist of the time

An instance of this tendency may also be found in the reported comments on economic growth in India by Alan Greenspan. Having first castigated Nehru's "Fabian socialism", Greenspan acknowledges the higher growth in recent years, but plays down the acceleration as having been from "off a low base". See 'Give up socialism: Greenspan', Times of India, New Delhi, 2007. Apart from its oracular nature the observation displays an empirical oversight in that India had already grown at over 5 percent per annum in the 1980s which was the highest rate of growth outside of East Asia by then. 
writing soon after the death of Nehru “... the percentage increase in national income in the last thirteen years has been higher than the percentage increase realised in India over the entire preceding half century." ${ }^{50}$ However, its remains to be established what brought about this transformation. Accounting for this transformation would serve a constituency larger than those with a particular interest in the recent history of India. It would constitute one answer to the larger question already flagged and of abiding interest to economists the world over, 'How do economies grow?"51

To get a handle on the task that confronts us we may start by eliminating the factors that clearly cannot be credited with the turnaround. Going by the conventional wisdom of today trade would be a prime candidate to consider as potentially crucial. For a sample of the view that openness is central to faster growth consider this: "Low or declining barriers to trade constitute a necessary condition for sustained rapid growth." ${ }^{2}$ This clearly is a non-starter in the context, for the fifteen years from 1950 had witnessed a progressive closing of the trade regime. Of course, export promotion is not necessarily at odds with a regime of imports controls, especially in the 1950s when international surveillance was not of the order that we find today. So it would not be entirely absurd to imagine export-led growth even in a relatively protectionist regime. But this is clearly not a reasonable description of the Nehru era when the economy had faced severe balance-of-payments stress, one coming soon after the death of Nehru, and in some ways reflective of the policies pursued under his leadership. In fact, as stated, Mahalanobis had been inspired by a vision of an India permanently freed from the balance of payments constraint but this was certainly not achieved even ten years after the launching of the Second Five-Year Plan. This, however,

50. Raj (1965).

51. See Scott (1997)

52. Panagariya (1997), p.7. 
is the right moment to remind ourselves that a balance of payments surplus is not a recipe for faster growth. It is instructive in this context to note that India had ended its colonial period with positive sterling balances. Nevertheless, the period 1900-47 was one of the most stagnant phases in India's recorded history. To take a more contemporary example, in the second half of the twentieth century, Africa has remained one of the more open economic areas of the world. ${ }^{53}$ However, this has not prevented it from remaining the most depressed.

Let us now consider another possibility among factors responsible for faster growth in India. This is the end of colonialism. It is interesting that while discussing the history of globalisation some ignore the fact that in the nineteenth century much of the non-European world was colonised. As a response, Milanovic (2003) has argued that to judge the history of globalisation purely by growth rates without reference to the colonialism $^{54}$ that had shackled these economies is really to miss a significant aspect of the reality and detracts from such growth that may have been achieved, even if in some cases quite substantial. My reference to the reality that India was a colony for about two centuries prior to 1947 is significant in another way though. This is that the Indian economy had been subjugated to Britain's imperial interests, stifling India's potential. Though some economists today tend to overlook this ${ }^{55}$ it was recognised by Indian entrepreneurs of the time. In particular, the visionary nationalist engineer M. Visveswaraya (1936) has written extensively of the obstructions by the colonial Government of India that Indian industrialists had faced in their plans to invest in new projects and points to this as reason for the failure to industrialise ${ }^{56}$ the Indian sub-continent. A simple test of this would be whether the tide turned after the end of

\footnotetext{
53 Castells (2000).

54 See also Nehru (1946).

55 See Lal (1999).
}

56 See also Bagchi (1972) for a contemporary economist's perspective on the period. 
colonialism and India's entrepreneurs, set free from the colonial yoke, led a turnaround of the economy. This is a proposition difficult to test, as 'everything else' did not 'remain the same' violating ceteris paribus the very staple of economists. Principally, the post-colonial state had adopted a role which would have profound implications for private sector behaviour. On the one hand it intervened in the economy by raising public investment which is likely to have provided demand, and therefore greater profits than otherwise, for the private sector's product. On the other hand, it intervened heavily in some sectors. Indeed, in the minds of some, it stifled the private sector as much as it had been stifled by the colonial Government of India. In any case, the change in the overall policy regime makes it difficult to deny that Indian entrepreneurship was stifled under the Raj even if the private sector is seen not to have led the revival after 1947. But more importantly, we have seen that the revival of the Indian economy was broad based ${ }^{57}$ while the sector that had allegedly been suppressed most, in order to further British industrial interests, during the colonial era was the manufacturing sector. So the end of the colonial subjugation of India cannot per se be credited with the subsequent rise of India, even though the end of colonialism was sine qua non for an enabling political environment for India's development. The reason for this must be sought in some more active agency. How then was the dramatic turnaround of India achieved? There can be no doubt that it was state directed ${ }^{58}$. However, it yet remains to provide an account of the mechanism.

The quickening of the economy follows the overcoming of a 'coordination failure' that had left India in a low-level equilibrium trap 59

\section{See Table 1.}

58. Indeed, this must be the obvious conclusion of those who claim that an excessively interventionist state in India under Nehru had left the private sector ham-strung.

59. The rest of this section draws substantially on the imaginative portrayal of this view of economic underdevelopment by Ray (1998). 
for close to half a century. To see how low levels of income can result from co-ordination failure we need to first apprehend the idea of complementarities among economic activities. This is best understood in the context of a firm considering making an investment. A central element in this decision problem is the firm's forecast of its future productivity. Now this productivity depends upon the future path of average capital accumulation by all firms in the economy. If our firm believes that this path will swiftly rise it would predict a correspondingly high rate of growth of its own productivity, because of the 'externality' involved. Where firms hold identical expectations each firm will be more willing to invest, raising the rate of growth of its capital and thus income in the economy. We see here that the decision to accumulate capital by one firm provides an incentive for others to undertake the same action. This is the externality referred to. Here it takes the specific form of a complementarity in that capital accumulation by one firm encourages capital accumulation by others.

It was Rosenstein-Rodan, reflecting upon the question of the reconstruction of a war-torn Europe, who had identified the role of complementarities in precipitating a low level equilibrium trap. He had proposed that a low level of income is the outcome of an economy-wide co-ordination failure, in which some investments do not occur simply because other complementary investments are not made and the latter are not forthcoming only because the former are missing. It is possible to comprehend this from the decision problem of the firm that we had considered. At a very general plane one firm's investment is the source of another firm's profits making this other firm viable, thus providing it the incentive to invest.

Co-ordination failure results as follows. Where no entrepreneur is large enough to invest in more than one line of activity each entrepreneur would invest only if he were to believe that others would invest as well. Now we have two possible equilibria: one in which the region is devoid 
of any investment at all and another in which there is investment by all (as expectations are uniform across firms). This has been referred to as a 'co-ordinated equilibrium' in that each firm's decision is based on its expectation of the behaviour of others resulting in an outcome coordinated in this sense. In this account a low-level equilibrium is a market failure. A better outcome - with income high - is possible, but is not necessarily attained in an economy of free agents maximising profits. Notice that whether or not such an outcome arises depends upon each agent's expectations of the actions of others. To the extent that the formation of expectations is driven by past history, a stagnant society could remain so whereas an active one would remain active, even though there may be nothing intrinsically different between the two regions.

The idea of a co-ordination failure - whereby an economy is trapped in a 'bad' equilibrium when a more desirable one exists - is particularly compelling in a diverse economy with industries developed to a different degree, if only for the reason that now co-ordination across these many diverse industries would be required. Such diversity is likely to be appropriately descriptive of the Indian economy at independence. If 'coordination failure' describes well the stagnant state of the Indian economy at that point in time, it is also easy to imagine the complexity of the task of achieving a co-ordinated expansion to a higher level of income in a large and diversified economy.

The early literature on development economics had proposed two solutions to the co-ordination problem. To understand them we need to take on board the concept of linkages. This concept springs from the view that the economy is an interlinked entity. Hirschman (1958) had conceived of backward and forward linkages. Forward linkages ease the supply conditions of a sector. Thus the steel industry facilitates the development of the railways by making available a crucial input at a lower price. On the other hand, a backward linkage raises the demand for the product of a sector, as when the development of the steel industry 
historically raised the demand for coal. Forward linkages push the economy while backward linkages pull it so to speak. This feature, that an economy is interlinked, provides the means and an opportunity to shift the economy out of a co-ordination failure that leaves it stranded at a low level of income. Rosenstein-Rodan had proposed a Big Push, being a programme of co-ordinated investment in several sectors meant to shock an economy out of its slumber so to speak. Such a policy has two requirements. The first is economic in that a very large investment outlay is needed to make a difference. The second requirement is informational. The 'co-ordinator' - reasonably assumed to be the state alone - must have an idea of the proportions in which consumers spend their income on the different commodities, or we could end up having too much coal and too little soap, for instance. However, the existence of linkages between the sectors of an economy enable the co-ordinator to overcome both these. This takes us to the solution proposed by Hirschman.

Hirschman had pointed out that Rosenstein-Rodan's proposal of investing in the major sectors simultaneously was akin to promoting balanced growth in the economy. Instead we could envisage unbalanced growth, a situation where the initial investment is targeted on some specific sector(s). Indeed, the idea is to deliberately foster unbalanced growth by investing in certain leading sectors. With this, linkages both forward and backward are activated and the production response gets the whole economy moving. Exactly as does the Big Push, this strategy too shifts the economy onto the desirable equilibrium. However, it differs in that it makes use of the market, exploiting potential linkages, with the government presumably investing only in the leading sector. Note that this strategy is less vulnerable to the two requirements of the Big Push, for here both the scale of the public investment entailed and the informational requirement are likely to be less. But where the government's investible resources are limited and not all sectors are equally endowed with linkages the question of which sector to choose is not a trivial one. It is obvious that the sector(s) chosen must possess both 
numerous and strong links. However, it is a less obvious criterion that emerges as of interest, that of the intrinsic profitability of a sector. In the context, this is a treacherous concept as we had introduced the idea of a complementarity by arguing that the profitability of an investment depends upon investments elsewhere in the economy! But let us overlook the circularity that this implies and persist with the idea of intrinsic profitability best captured by the American expression 'bang for the buck'. Once we have arrayed activities according to their intrinsic profitability, the investment priority of government would be the exact reverse of that of the private sector. That is, in the context, the government's priority would be to first invest in the least profitable sector because this is unlikely to be taken up by the private sector. Exactly as a chain is only as strong as its weakest link, “... the government maximises the chances of overcoming coordination failure by investing in the least profitable activity, provided of course that such activities have linkages as well." ${ }^{60}$ Now choosing the least profitable sector while leaving the rest to the market is actually of strategic intent.

This extended foray into the debates in early development economics was meant to provide a window onto what was attempted in India in the Nehru years. We of course know that, in a bid to quicken the economy, a programme of massive public investment was initiated with the onset of planning in 1951. However, it is of interest yet to understand how precisely this may have worked to bring about the dramatic rise in the rate of growth. Debraj Ray ${ }^{61}$ has imaginatively suggested that the Mahalanobis Model was essentially a scheme for promoting unbalanced growth, with heavy industry as the leading sector. It is certainly true that heavy industry has substantial linkages with the rest of the economy forward into agriculture and backward into consumer goods and services. Ray's is an interesting insight and appears to be borne out by the data on

60. Ray (1998), p. 141.

61. Ray (1998), pp. 142-3. 
the sectoral allocation of investment in the Second Five-Year Plan presented in Table 3. We find that, in line with popular perception, 'Industry' does get the largest share of the outlay. However, this is not overwhelmingly so. First, there are sectors that come close to having been allocated a similar share. Secondly, and in any case, industry's share does not exceed twenty five percent. Therefore, while this may count for its being singled out as the 'leading' sector, the suggestion of an 'unbalanced growth' strategy having been pursued would appear inappropriate as a characterisation. Of course, in relative terms industry was allocated much more than agriculture than conveyed by the figure for industry per se for it had a much smaller share of GDP than agriculture in 1956. But what strikes one most after a gap of half a century is how well-balanced the allocation of investment appears to be given India's needs at that stage. Also, the large allocation to industry must be seen in perspective. I repeat a point made by me earlier and one that I shall return to. This is that the planners had envisioned industrialisation contributing directly to raising agricultural productivity and thus agricultural growth. This is a case of recognising (forward) linkages, even a little before the publication of Hirschman's article on unbalanced growth as a strategy. Nevertheless, though the Mahalanobis model, that

Table 3: The allocation of public investment in the Second Five-Year Plan (in Rupees crores)

\begin{tabular}{|l|c|c|}
\hline Sector & Outlay & Share \\
\hline Electricity & 450 & 13.2 \\
\hline Industry & 1000 & 29.4 \\
\hline Transport and Communication & 850 & 25.0 \\
\hline Agriculture and Irrigation & 750 & 22.1 \\
\hline Construction & 250 & 7.4 \\
\hline Stocks & 100 & 2.9 \\
\hline
\end{tabular}

Source: 'Recommendation for the Second Five-year Plan', Planning Commission, 1956. 
had undergirded the drive to industrialisation launched by the Indian state, did have as its central element the heavy goods sector - with similarity to a strategy of unbalanced growth - I find it more convincing to see the quickening of the Indian economy as due to a Big Push driven by expanding public investment ${ }^{62}$. Not only was there a wide spreading of this investment across the economy, as depicted in Table 3, but the economy had already quickened ${ }^{63}$ before the launching of the Second Five-Year Plan, and all the sectors were to accelerate again, though at differing points, over the next three decades. However, the most important reason for rejecting an unbalanced-growth type explanation for the acceleration of growth in India during the Nehru era is that the acceleration was very likely led by agriculture. This may be surmised by taking the data in Table 1 along with the additional information that agriculture constituted by far the largest share of the economy in the 1950s. Recall that a sector's contribution to overall growth is its shareweighted growth rate. The full contribution to Indian economic development of the state-directed heavy-industry-drive was to come much later, and some suggest continues to this day. ${ }^{64} \mathrm{Be}$ that as it may, the industrial sector did expand substantially ${ }^{65}$ in the Nehru era. Its accelerated growth during this period along with that of the agricultural and services sectors indicates the 'movement along a broad front' that is the hallmark of the Big Push strategy.

The argument that the expansion of the Indian economy in the post-colonial era may be seen as due to a state-directed drive such as a Big Push is properly verified by reference to the data on public investment. Data on saving and investment by the public and private sectors are provided in Table 4.

62. For a suggestion along these lines see Rao (2004).

63. See Balakrishnan and Parameswaran (2007).

64. See Reddy (2006).

65. See Table 1. 
Table 4 : Saving and Investment (\% of GDP)

\begin{tabular}{|c|c|c|c|c|c|c|}
\hline \multirow{2}{*}{ Year } & \multicolumn{3}{|c|}{ Private corporate sector } & \multicolumn{3}{|c|}{ Public sector } \\
\hline & S & I & (S-I) & S & I & (S-I) \\
\hline $1950-55$ & 1.0 & 1.4 & -0.4 & 1.7 & 3.1 & -1.4 \\
\hline $1960-65$ & 1.7 & 3.6 & -1.9 & 3.0 & 7.5 & -4.4 \\
\hline $1989-90$ & 2.1 & 3.9 & -1.8 & 1.7 & 10.7 & -9.0 \\
\hline
\end{tabular}

Source: National Accounts Statistics, CSO.

All of it points to the plausibility of the explanation that I have provided. Several points may be noted. First and foremost there is a very substantial expansion of public investment as a share of GDP. Such an expansion, exceeding two and a half times the original figure by the end of the Nehru era, has not been matched in India for the next quarter century $^{66}$. Though not apparent from the highly aggregative data presented here it is not only the magnitude of the expansion of public investment that is significant, but also its direction. As in a Big Push, investment was to have flowed in all directions ${ }^{67}$ simultaneously. Contrast this with the limited public spending outside of administration and the railways by the colonial government. Interestingly, there is an almost identical expansion of the private corporate sector during this period. This too is unmatched for the next twenty five years ${ }^{68}$. Some comments would be appropriate. The first concerns causality. Even though the expansion is contemporaneous, going by economic theory we would imagine the public sector contributing to the expansion of private investment by having expanded the market for its goods and at the same time supplying the capital goods necessary at a lower price. Secondly, the degree of expansion of the private sector in the Nehru era

66. See Table 4.

67. See Table 3.

68. See Table 4. 
is perhaps little known today and seldom recognised as a feature of the period. However, this record makes it a little difficult to sustain the argument that the policy regime was relentlessly hostile to it. Added to this is the fact that the expansion of the private sector was also very likely financed by the other sectors within the economy. Note that the saving-investment gap for the private corporate sector widened very substantially during this period. This implies that corporate investment was financed by the household sector, the external sector and by the public sector ${ }^{69}$ itself. Therefore, it is not as if, in the era of high planning, the private sector had had to pull itself up by its bootstraps. Of course, this could have neutralized none of the heavy-handedness of a bureaucratic approach that may have stifled many firms and retarded private-sector development. However, judging by the expansion in investment, it would not be inappropriate to surmise that the private corporate sector as a whole appears not to have done too badly ${ }^{70}$ in the Nehru era.

The role of the government in quickening the economy in the second half of the twentieth century is unmistakable. It was of course in keeping with the plan of the Indian state. However, the government's calculations, had in the process, gone awry on one count. This pertains to the role of external assistance in financing plan outlay in the public sector. As I have already pointed out, the proposed budget for the Second Five-Year Plan had anticipated for foreign assistance a share of only 5 percent in total public expenditure. The outcome was to turn out far different. The shares of different sources in the financing of public sector outlay during the Nehru era (and slightly beyond, as we have included the entire Third Plan period) are to be found in Table 5. Note that the

69. “... investment in industry in the private sector (was) largely assisted by financing institutions in the public sector, and by fiscal concessions and tax incentives provided by Government", Rao (1971), p. 72.

70. For a qualitative assessment of the gains to the private sector during the Nehru era see Zachariah (2004). 
figure recorded for the Second Plan had exceeded by far the figure of 5 percent. More significantly, the share of foreign assistance had risen steadily after the commencement of planning.

Table 5: Financing of the Public sector Plan

\begin{tabular}{|l|r|r|r|r|}
\hline & \multicolumn{1}{|c|}{$\begin{array}{c}\text { First } \\
\text { Plan }\end{array}$} & $\begin{array}{c}\text { Second } \\
\text { Plan }\end{array}$ & $\begin{array}{c}\text { Third } \\
\text { Plan }\end{array}$ & $\begin{array}{c}\text { Seventh } \\
\text { Plan }\end{array}$ \\
\hline Own resources & 38.4 & 26.3 & 33.8 & 27.4 \\
\hline Domestic capital receipts & 35.0 & 30.8 & 24.8 & 48.9 \\
\hline Net foreign inflow & 9.6 & 22.5 & 28.2 & 8.7 \\
\hline Deficit financing & 17.0 & 20.4 & 13.2 & 15.1 \\
\hline Total & 100.0 & 100.0 & 100.0 & 100.0 \\
\hline
\end{tabular}

Source: Bagchi and Nayak (1994).

The role of foreign assistance in financing the public expenditure which in turn had stepped-up the rate of growth in India cannot be overlooked. Indeed, by the end of the Third Plan, at close to 30 percent it was a significant input. This is mostly glossed over. However, three observations may be made related to foreign inflow to public expenditure in India. First, except for the Soviet Union it is difficult to think of many other countries that have transformed their economies so rapidly without external financing. The United States had received British capital and Britain in its time had had its trade surplus with India, arguably some of it disguised plunder. China had ${ }^{71}$ had aid from the USSR and South Korea from the United States. So foreign assistance per se does not take away from India's achievement in transforming her economy quite rapidly and against significant odds. Secondly, by comparison with other developing countries attempting a similar transformation at that time, the amounts received by India were not large in relation to its size. For

71. Indeed also in the unique form of "complete plant installations for machinebuilding industries" as trade credit. See Raj (1967), p. 24. 
instance, at US\$1.8 - being the average for the years 1962 and 1963 the aid per capita received by India was a fifth of that received by south Korea and less that thirty times that received by Israel. In 1964-65, total aid - loans and grants - stood at 3.5 percent of national income ${ }^{72}$. Finally, it is significant that, at least during the Nehru era, aid did not compromise India's economic policy. As Bhagwati and Desai (1970) have observed: "By and large the aid has gone towards 'Industrial Development'. This is in keeping with, and sharply underlines, the general Indian strategy of development as also the economic philosophies of the time which underemphasised the productive significance of expenditure on education and other social services as also the role of agriculture." 73 Indeed, India's position appears to have been stronger than it is today when in somewhat frantically seeking foreign direct-investment by show-casing its economic arrangements it appears to have lost a sense of its priorities, the haste to usher in full capital-account convertibility being the most noticeable case in point. Of course, more than any particular strength of India's the ready availability of external funding for her economic plan in the 1950s had to do with the international politics of the time. The Nehru era had coincided with much of the Cold War and as a non-aligned country India had been sought after by the protagonists on both sides. While Soviet aid had come early and without strings, aid from the west and the multilateral loans under the aegis of this grouping predominated over loans from the Eastern Block though they did come at a higher rate of interest ${ }^{74}$. There is altogether little reason to believe that Indian economic policy had been influenced by excessive dependence on borrowing from any particular source. On the contrary, Kalecki ${ }^{75}$ surely had had India in mind when he compared the non-aligned countries to calves that sucked milk from two cows!

72. See Bhagwati and Desai (1970), p. 181and Table 10.3.

73. Bhagwati and Desai (1970), p. 187.

74. Bhagwati and Desai (1970), Tables 10.1, 10.2 and 10.5.

75. Kalecki (1993). 


\section{Caricature of a vision: Through a glass, darkly}

In a final section I address some lingering misperceptions regarding the Nehru-Mahalanobis Strategy and the outcome of the policies that had been adopted as a consequence. Though these are often propagated by simplistic or, worse still, sentimental readings I consider it important to do so as the allegation that we continue to pay for a misguided road map is a serious one.

\section{IV.1 'The neglect of agriculture'}

There are two ways in which a sector can be neglected. First it could be ignored in the policy discourse itself, with insufficient attention devoted to its problems. Negligence could also take the form of insufficient resources being devoted to the desired expansion of a sector. I have already suggested in the course of the discussion so far that agriculture had received direct attention and considerable resources during the Nehru era. To widen the window I first present the view on the matter of two economists of the time, and then return to provide my own perspective. V.K.R.V. Rao, an early doyen of Indian economists, had had a ringside view of the Indian economy for over five decades starting about 1940. He has had the following to say: "It has been alleged that the priorities assigned ... in India's planned development have been based on a mistaken imitation of Soviet planning and that higher priority should have been given to agriculture and consumer industries instead of to capital goods industries. ... The emphasis placed on capital goods industries was the result of an understandable desire to furnish the country with domestic supplies of the crucial inputs of economic growth so that the rate of growth could be much faster than if the country had to rely essentially on foreign aid for its requirements of capital and intermediate goods. Apart from this it is not correct to suggest that planning under Nehru did not give sufficient priority to agriculture. In fact, of the total investment undertaken during the first three Five-Year Plans ...... agriculture, including irrigation, accounted for Rs. 3, 446 crores, or 22.7 
percent, while economic infra-structure, like transport andcommunications, and power, accounted for Rs. 5, 737 crores or 37.7 percent and social services for Rs. 2, 760 crores or 18.1 per cent. Industry accounted for only Rs. 2, 651 crores or 17.2 per cent of investment in the public sector during the fifteen years covered by the three Plans." 76

Raj Krishna was an economist in a very different mould from V.K.R.V. Rao. Chicago-trained and, in the political climate of the time, with a reputation for being somewhat of a right winger, he was perhaps a more acute an observer of the Indian economy than most of his peers. Overall, Raj Krishna suggests that there may have been mistakes only in the proportions in which investment had flowed into different channels rather than " $\ldots$ in the choice of the plural strategy which had always characterized Indian planning." On the specific issue that we are considering he has stated: “ ... Nehru, as indeed all planners, attached prime importance to agriculture. Nearly a fifth of the public sector Plan outlay has been consistently allocated to agricultural development. In addition, heavy investments were made in industries producing agricultural inputs and processing agricultural outputs. There was a massive increase in the flow of credit to the agricultural sector from Rs. 70 crores in 1950-51 to Rs. 2, 000 crores in 1975-6. Almost all agricultural inputs are subsidized; agricultural income is lightly taxed, and during the last thirteen years minimum prices, covering the full cost of production have been guaranteed for all major crops. This set of policies can hardly be described as embodying the neglect of agriculture. But the fact still remains that the allocations for agriculture (particularly irrigation, extension and fertilizer production) and for rural infrastructure and social services could and should have been higher."77 The facts of the case, at least with respect to the allocation of resources, as presented by Rao and Krishna must persuade all but the willful disbeliever. Of course, it would

76. Rao (1971), p. 72.

77. Krishna (1982), p. 60. 
be the case that in per capita terms the direct allocation to agriculture was certainly lower than that to industry as the rural population dwarfed every other cohort in the economy. But this would be a myopic approach to things. To state somewhat differently a point already made, planned industrialisation was hardly a rival to agricultural expansion as Mahalanobis had seen it. On the contrary, faster agricultural growth it was diagnosed needed more industrial inputs, whether fertiliser for nutrient replenishment, iron and steel for implements or cement for irrigation conduits. Moreover, agricultural production was relatively free from controls in the Nehru era while private industry was subject to stringent policy controls, notably licensing.

There is of course an entirely different approach to assessing the belief that agriculture was neglected. This is to account for intent by outcome rather than pronouncement. Now only the performance matters. We have already looked at the data on agricultural growth in the Nehru era though nested within the larger category of 'Primary Sector'. The data presented in Table 1 shows unambiguousy that the agricultural sector grew very impressively under Nehru, recording the highest growth among all sectors and making a dramatic recovery from the colonial era. This can hardly be seen to result from negligence ${ }^{78}$. Indeed, the scale of this achievement and the role of political agency in the form of leadership is fully comprehended only when we study in some detail the state of Indian agriculture in 1947.

Though it is the de-industrialisation of India under colonial rule that has received most attention it is decimation of the countryside that is perhaps the leitmotif of the British Raj. For a century and a half, ending with the Bengal Famine of 1943, there had been some devastating famines in India with one particular famine in Bengal under the East India Company in the eighteenth century wiping out an estimated one third of the population. These famines were directly related to the policies of

78 For a rejection as "simplistic" of the claim of the neglect of agriculture under planning see Srinivasan (1996). 
extortionate taxation and forced commercialisation of agriculture pursued by the Company. As historians have provided outstanding accounts and analyses of these events I go directly to summarise the findings of George Blyn on the trend in output in the first half of the twentieth century. Blyn had divided the period 1891-1947 into ten overlapping ten-year slices which he termed 'reference decades'. He then estimated the average annual rate of growth and the change in the rate of growth across these reference decades for foodgrains and non-foodgrains separately. To help focus a little better on his findings I have collected in Table 6 the estimates for foodgrains. This data presents us with an unedifying picture of Indian agriculture under the Raj. First, the rate of growth of foodgrains as a whole is far lower than the rate of growth of population implying, declining availability. The output of rice, the grain consumed by the largest number in India then (and now), actually declines. His findings are summarized thus by Blyn: "In the most general measure of the change in rates over time, the trend in reference decade rates, all eight foodgrains

Table 6: Agricultural growth in British India

\begin{tabular}{|l|c|c|}
\hline \multicolumn{1}{|c|}{ Crop } & $\begin{array}{c}\text { Average annual growth } \\
\text { over ten reference-decades }\end{array}$ & $\begin{array}{c}\text { Change in the reference- } \\
\text { decade rates of growth }\end{array}$ \\
\hline Aggregate & 0.11 & -0.17 \\
\hline Rice & -0.09 & -0.03 \\
\hline Wheat & 0.84 & -0.09 \\
\hline Jowar & 0.05 & -0.12 \\
\hline Gram & 0.26 & -0.34 \\
\hline Bajra & 0.72 & -0.11 \\
\hline Barley & 0.02 & -0.55 \\
\hline Maize & 0.51 & -0.17 \\
\hline Ragi & -0.37 & -0.23 \\
\hline Population & 0.67 & 0.11 \\
\hline
\end{tabular}

Source: Blyn (1966), p. 96. 
showed retardation."79 The record of non-foodgrains is better with a far greater average growth rate in the aggregate. However, this reflects precisely the nature of the colonial project which was the exploitation of the natural resources and commandeering the market of the colony for the benefit of metropolitan industry. Indeed, the glacial progress of foodgrains production is directly related to this strategy, implemented partly through price incentives and partly by brute ${ }^{80}$ force. Food supply for the native population faced collateral damage.

The performance of the economy in the Nehru era must be evaluated in light of the agricultural legacy of colonialism. To have brought about two accelerations ${ }^{81}$ in the rate of growth of agriculture within two decades of the end of colonial rule is nothing short of

79. Blyn (1966), p. 96.

80. "Not a chest of indigo reached England without being stained with human blood.", British colonial civil servant quoted by Winchester and Winchester (2004), p. 56.

81. The information presented in Table 1 reflects only the first acceleration as we have there treated the entire period after 1950 as one. For a demonstration of the acceleration in agriculture towards the end of the first half of the sixties see Balakrishnan and Parameswaran (2007). Even if the acceleration per se is established to have occurred immediately after the death of Nehru, the Green Revolution ought not to be seen as episodic but the result of some years of preparation of the seed bed, so to speak, in terms of the spread of irrigation, the diffusion of best practices via an extension, and preparatory measures such as field trials under the auspices of in the public agricultural research system ICAR some of these commencing in the First Fiye-Year Plan. The comment by AM (1964): "Despite all the gains of the last seventeen years, in many respects we have to make up for the lost time of these very years, during which all of us have grown a little less romantic and during which our per capita availability of food has not gone up by a single grain." is appropriately cautionary but wrong in its claim regarding the progress in agriculture. The per capita net availability of grain had grown slowly but steadily over the Nehru era despite the significant rise in the population growth rate. Of course, that the performance could have been better is unexceptionable, but two caveats are in order here. First, subsequent growth in availability of foodgrains in India has barely matched the record of this period. See 'Economic Survey 2006-2007, Table 1.17. Secondly, the Nehru era is the only phase in the history of post-Independence India when the relative price of food crops actually declined, for which see Appendix Table 4.4 in Mishra (2004) . Apart from the fact that this would be considered the pre-eminent marker of development, it is the best imaginable evidence that the Nehru-Mahalanobis Strategy encompassed the Vakil-Brahmananda Plan which had predicated a wagegoods constraint binding Indian economic growth. 
spectacular, and places in perspective the lingering grievance that agriculture was ignored in comparison with the attention paid to industrialisation in the Nehru-Maahalanobis Strategy. Indeed we need to recognise the reversal of the retardation of the agricultural sector in the first half of the twentieth century as one of the great achievements of independent India, and this was entirely achieved in the Nehru era. I submit this radically revised reading of the period.

\section{IV.2 'The public sector enterprise as black hole'}

The second misperception of the policies of the Nehru era pertains to the idea of the public sector. In India today there is an unmistakable frustration with the public sector. It is associated with a poor performance record, resented for its lack of innovation, disdained for its contempt of social responsibility and considered a draft on the public resources. On the last, an additional consideration from further left, beyond the leftwing parties often in power in some states, would be that it is financed disproportionately by the poor who are not among its principal beneficiaries. Much of this is not off the mark as a description of the true state of affairs. However, the belief, among most, that this outcome is intrinsic to the Nehruvian conception of the public sector is far from correct. In this section I undertake two tasks. I first establish the rationale for the setting up of a public sector in India. I then consider one indicator of its performance during the Nehru era.

I choose to analyse the original idea of the public sector and its performance record during the Nehru period within the overall project of resource mobilization. This would not be considered unusual, for the hallmark of any successful developmental effort is the mobilisation of resources. It is not necessary that the resources mobilised must be contained within the public sector. After all, private investment is an equally legitimate component of aggregate investment in an economy. However, in the context of Indian industrialisation, launched in the 1950s, a large part of this mobilisation would necessarily have had to be in the 
public sector as it was intended that the state would have the leading role here. For planning to be effective, there is required, if not a concentration in its hands, at least an adequate ${ }^{82}$ fund base for the state. Where an economy is at a low income level the requirement is likely to be large, in turn requiring the productive surplus to come progressively into the public sector thus enabling it to maintain command over resources ${ }^{83}$. In this section, I first present views on resource mobilisation and the role of the public sector enterprises within that overall objective of both the government and of independent economists then active. Subsequently, I study the evidence on both resource mobilisation and the contribution of the public sector to it.

As the Second Five-Year Plan constituted the single largest instance of resource mobilisation during the Nehru era it's documentation is likely to be the best source of the government's view on the question of interest to us here. In the section titled 'Financing' of the 'Recommendation for the Second Five-Year Plan' by the Planning Commission ${ }^{84}$ we find: "Large financial resources would be required for the Second Plan. A small portion would come from sterling balances or foreign loans and aid; and the bulk of the resources must be found from within the economy. The tax system would be directed to collect an increasing part of the growing national income in order to permit greater capital formation in the public sector and to finance an expansion of social services. The public sector would be extended to industrial and commercial activities where necessary for raising resources for public purposes." 85 This is

82. Oddly enough, while this is barely recognised by professional economists it is widely recognised within civil society. See the report on a debate in Kerala today in Mathrubhumi (2007).

83. A strong public-sector resource base is required also in high-income economies with substantial welfare interventions, for instance, the economies of Western Europe.

84. See Planning Commission (1956).

85. Planning Commission (1956), p. 27. 
echoed in the Industrial Policy Resolution of 1956, which states that the public sector was expected to "... augment the revenues of the state and provide resources for further development in fresh fields". ${ }^{86}$ We find that the official idea of the public sector was not welfarist. In particular, the idea of having a public sector at all was to raise resources for public purposes. Of course, this is not inconsistent with a strong welfare orientation. The issue point though is the role imagined for the public sector when planned economic development was launched in India.

The need for very significant resource mobilisation and the role of the public sector in relation to that task was also recognised by the independent economists of the day. Emphasising that “... the effort involved in this increase is considerable, and will strain the economy a very great deal ....", the economists empanelled by the Planning Commission had spoken of " ... the great difficulty of increasing tax proceeds unless a fundamental revision in current concepts that underlie the tax system is accepted. One of these concepts relates to the exemption of essentials from the scope of an important part of commodity taxation. When so large a measure of effort is necessary to increase the proportion of tax revenues to national income, which has remained so obstinately static, one cannot escape the logic of the fact that the mass of consumption is by the mass of the people. Unless this bears a somewhat higher burden of taxation, no perceptible change in the stubborn ratio of public revenues to national income can be achieved. We wish to endorse in particular, the Recommendation of the Taxation Enquiry Commission to the effect that Article 286(3) of the Constitution may be amended to remove the present exemption of articles "essential to the life of the community" from the scope of state sales taxation. Simultaneously, measures to secure a practical ceiling on incomes through a steepening of taxes on income and wealth, including estate duties, becomes an imperative necessity. $A$ revision of the price policy of important public enterprises with a view

86. Cited by Krishna (1988). 
to obtaining a larger surplus as a contribution to the resources for economic development is similarly required. Besides the general increase in rates of direct and indirect taxation that will be involved in the considerable stepping up of tax effort will be part of the challenge to administrative efficiency that the big development effort for putting through the next Plan entails." 87 Apart from the replication of the views of the government on the role of the public sector, quoted earlier, two points may be noted. First, the independent economists had recognised the serious resource mobilization effort entailed in the plan to industrialise. Secondly, note the complete absence of populism in the recommendation that in the short-run even the convention of excluding essentials from taxation may have to be put in abeyance. The unstated expectation of the public sector are reflected in the government budget proposed in the document 'Recommendation for the Second Five-Year Plan'. There, as I have pointed out once already, the profits from state enterprises along with 'additional taxes and loans' exceed the amount of foreign assistance ${ }^{88}$ allowed for and when combined with the contribution from the Railways amounts to close to one eighth of the total outlay. Finally, it is most instructive in the context to read Mahalanobis: "In the highly developed countries of the West, taxes on commodities are usually looked upon as "regressive", as being a burden on the poor. Public enterprises are also expected to be run on a no-lossno-profit basis. Fortunately, our outlook is changing and it is being realised that in an underdeveloped country like India excise and customs duties, purchase tax on commodities or a levy on services would be convenient and adaptable methods to raise resources. It is also agreed in principle that public enterprises should earn and contribute increasing returns for purposes of national development." 89 One thing is clear from

87. From 'The Second Five-year Plan: Basic considerations relating to the Plan frame', Memorandum prepared by the panel of economists constituted by the Planning Commission, published in 'Sankhya' (1955), p. 115. Italics are mine.

88. See Mahalanobis (1964), p. 41.

89. Mahalanobis (1960), p. 97. 
these records of the time. Unlike today, populism was clearly treated with contempt by the architects of economic policy in early independent India.

While we may by now have an idea of the original conception of the role of the public sector in India, we are yet to have a picture of its performance. First, it may be repeated that a surge in public investment had been achieved in the Nehru era, a fifteen-year record of expansion that has not been surpassed. Secondly, the share of public savings in

Table 7 : Public sector savings (in current rupees crore)

\begin{tabular}{|l|c|c|c|c|}
\hline year & $\begin{array}{c}\text { public } \\
\text { sector }\end{array}$ & $\begin{array}{c}\text { public } \\
\text { authorities }\end{array}$ & $\begin{array}{c}\text { public non- } \\
\text { departmental } \\
\text { enterprises }\end{array}$ & $\begin{array}{c}\text { private } \\
\text { corporate }\end{array}$ \\
\hline $50-51$ & 168 & 159 & 9 & 89 \\
\hline $51-52$ & 252 & 243 & 9 & 132 \\
\hline $52-53$ & 145 & 129 & 16 & 60 \\
\hline $53-54$ & 127 & 107 & 20 & 86 \\
\hline $54-55$ & 151 & 126 & 25 & 114 \\
\hline $55-56$ & 172 & 145 & 27 & 130 \\
\hline $56-57$ & 231 & 193 & 38 & 151 \\
\hline $57-58$ & 245 & 195 & 50 & 117 \\
\hline $58-59$ & 227 & 170 & 57 & 136 \\
\hline $59-60$ & 236 & 176 & 60 & 180 \\
\hline $60-61$ & 425 & 362 & 63 & 276 \\
\hline $61-62$ & 494 & 426 & 68 & 315 \\
\hline $62-63$ & 566 & 480 & 86 & 338 \\
\hline $63-64$ & 709 & 586 & 123 & 387 \\
\hline $64-65$ & 817 & 679 & 138 & 381 \\
\hline
\end{tabular}

Source: Author's estimates from National Accounts Statistics 1950-51 to 1987-88, Table 9, CSO 
total savings had risen ${ }^{90}$ by the end of the period. Though the extent of this increase is not much greater than that of the private corporate sector it is still noteworthy that the expansion of investment was led by an expansion of public saving, as was intended. We have in this an index of the role of the public sector in resource mobilisation. Of course, this is not an argument regarding the sufficiency of that mobilisation. While yet on the topic, I present evidence on the behaviour of public sector savings during the period that we are looking at here. In Table 7 are presented data on savings of the public and private sectors. The public sector has been classified further into the public authorities - comprising government administration and departmental commercial enterprises and the non-departmental enterprises - comprising government companies and statutory corporations. Note from the Table that while the expansion of savings in the public sector as a whole is as it is faster than the expansion in savings of the private corporate sector, within the former the non-departmental enterprises turn in a vastly superior performance compared to all groups. Though the non-departmental enterprises continue to improve steadily for the next twenty years or so, during no other phase is the quite spectacular growth in their savings during 1950-64 matched $^{91}$. Three caveats need be introduced, however. First, the rise in aggregate profits is not incompatible with instances of chronic loss-making by individual units. Secondly, the data cannot serve as a measure of profitability for which purpose we would need to factor in the volume of capital invested. And finally, this is not to be taken as a mark of the efficiency of the public sector, as we are almost certainly dealing with monopolies here.

Emerging from our discussion so far is a view of the public sector held by the leadership in the Nehru era that is entirely at odds with the perception of that period. It has not been sufficiently well recognised

90. See Rao and Sen (1985).

91. See Table 3 in Rao and Sen (1995). 
that the public sector was originally conceived of as an active agent of resource mobilization for development. Its transmigration into an flaccid employment-granting welfarist agency was to come only after the death of Nehru. For that very reason what we might today view with shock horror the extraordinary record of public sector savings highlighted in Table 4 is very likely to have been taken as comme il faut by Nehru himself. Consider the following extract from a speech made on the occasion of the inauguration of the second Hindustan Machine Tools Factory at Bangalore in 1961: "There is a certain uniqueness about this function and the factory. The uniqueness lies in the fact that this factory has been made out of the profits or the surplus of the older Hindustan Machine Tools factory and, rightly, therefore, it is called a gift to the nation by those who have been working in the old factory. This should be a matter of great satisfaction to all those who are concerned with the HMT factory." 92 However, though the record of the public enterprises during his time may have been seen as entirely appropriate the data presented in Table 4 must challenge somewhat some economists of today. Thus, referring to "the losses made by public enterprises", Jagdish Bhagwati has stated: "Capital-intensive white elephants in the public sector were supported on the basis of models that deduced that this choice of techniques would yield a higher savings rate and hence higher growth: a conclusion that would now sound laughable, had its consequences not been so tragic." 93 In the face of such strident commentary it is worth repeating that during the Nehru era the savings of the public enterprises actually grew faster than that of the private corporate sector.

92. From "A gift to the nation", reprinted in 'Jawaharlal Nehru's Speeches 19571963', Publications Division, Ministry of Information and Broadcasting, GoI. Interestingly, Nehru was not squeamish about acknowledging assistance from the West when he felt it necessary to do so. For the speech continues: "May I also refer to those who originally set up the plant here, the well-known Swiss firm of Oerlikons who laid the foundations? They built the first HMT plant and helped in training our people in the early stages, and their work has yielded this fine result."

93. Bhagwati (1998), pp. 6-7. 
Neither the official approach to them nor the actual record of the public enterprises during these years suggests that the public sector was one of the wasteful legacies of the Nehru era. Their drift in this direction owes more to the pure politics of a subsequent era when the public sector was turned into a vast machine for dispensing patronage and buying out politically the vested interests of the day. The evidence presented here also allows us to evaluate the assertion that dirigisme is recipe for a fiscal crisis of the state ${ }^{94}$. The growth of the central government's tax revenues, as share of GDP, in the fifteen years since 1950 had not been exceeded $^{95}$ even by the year 2000 . However, my aim here has been to establish that the public sector was a strategic intervention in the cause of growth, and that during the Nehru era it had delivered to a reasonable extent.

\section{V.3 'A model that could never have'}

There exists a strong body of opinion that directly links the relatively low growth recorded in India over the long haul to the flawed Nehruvian 'model'. Though it has already been established in this paper that the record of growth in the Nehru era is hardly disappointing, and we know that some of the narrative is intended as caricature ${ }^{96}$, this view needs to be addressed as it is often encountered. I shall consider criticisms from two angles, each representative of a view of what constituted the core of public policy in the Nehru era.

The first of the lines of criticism draws not so much on mainstream economics as on political philosophy, and perhaps precisely for that reason is more widely held. This line of criticism identifies state intervention as having stifled private enterprise. Add to this "a loss-

94. See 'Introduction' in Lal (1999).

95. See 'Public Finance Statistics 2004-5', Ministry of Finance, New Delhi: Government of India.

96. See Bhagwati (1998) for the description 'model for going backwards'. 
making public sector" and we have a strategy that far from mobilizing resources needed for development actually squandered them. The view is neatly summarized by Chibber thus: “... India's mistake was its very turn toward development planning in the first place, an economic strategy that relied so centrally on state intervention in markets." 97 Of course, in some spaces of the economy the loss of economic freedom due to state intervention in the Nehru era was indeed real. But it is important to have a measure of its extent. Prominent among the restrictions, and emblematic of the restriction of freedom of enterprise was industrial licencing. Instituted with a view to channeling resources according to plan priorities, industrial licencing did seriously limit the freedom to invest (including in capacity expansion) of the private sector. Moreover, even apart from defence and atomic energy - in which areas it is likely to have little interest in investing - private investment was mostly excluded from the utilities and much of infrastructure. However, the area over which licencing had had an impact must be seen in perspective. It was confined almost entirely to manufacturing, leaving out of its purview about 80 percent of the economy in the 1950s. Agriculture was a notable area of exclusion as it was the largest part of the economy. In addition to licencing there was reservation, with certain sectors - chosen mainly on grounds of their being 'traditional' - reserved for industrial units with capital investment less than a prescribed limit. In the language of a strand of development economics such intervention was 'distortionary' in that it would cause deviations from the market outcome. However, in a perverse sense the same intervention may be read as expanding (or 'protecting' as one's perception may dictate) the economic freedom of the beneficiaries of the reservation who in its absence may have been competed out altogether. So, to be precise, the reservation policy had limited the freedoms of the private corporate sector. The policy of reserving certain segments of the manufacturing sector for small units

97. Chibber (2003), p. 6. The author himself does not subscribe to this view, however. 
would have had the obvious impact of not allowing for any potential economies of sale to be reaped in these sectors. Among its consequences, it has been alleged, has been the destruction of India's more automated cotton textile industry which now had to face competition from a handloom sector itself protected from competition by the reservation policy.

The perception of a loss of economic freedom during the Nehru era is closely linked to the presence of controls. Further, whether by design or default much of these controls came to be referred to as 'socialism'. What is, however, interesting is that a large part of this structure had been instituted during the Second World War. Put in place by a colonial government guided not solely by the objective of protecting India but also of ensuring that finance and resources flow in a direction compatible with maintaining the Allied war effort globally, these controls encompassed economic activity from foreign trade, to capital issue, prices and even the internal movement of goods, notably grain. The origins and development of much of the controls in post-Independence India have been traced to the first half of the nineteen forties by Mohan and Agarwal (1990). Even the urban bias of the public distribution system can be traced to the colonial government's need to maintain the peace needed to continue the outward-oriented war effort. Two instances clarify the precise relationship of these controls to the Mahalanobis strategy. First, the debate at the time of the launching of the Second Five-Year Plan model was about the maintenance of the war-time controls and not the institution of a new set. Thus it was that B.R. Shenoy's note of dissent $^{98}$ had actually argued for its rescinding; there had been no proposal for a significant increase in controls as part of the Mahalanobis strategy, perhaps because the powers with the government since the War left it with sufficient clout to control economic activity. In particular the import controls came to evolve in an ad hoc manner after a balance of

98. See Shenoy (1955). 
payments crisis, itself precipitated by subsequent liberalization, interestingly, of consumer goods ${ }^{99}$ imports. Licencing, of course, did figure prominently in the Industrial Policy Resolution of 1956 providing the legislative muscle for the actualisation of planning for growth.

I conclude this discussion of the place and role of controls in the Nehru era with two observations. First, despite the allegedly debilitating impact of controls the economy did recover from almost half a century of stagnation. Moreover, it was the manufacturing sector - the area of the economy most subject to controls - that had recorded the fastest growth. Secondly, and this anticipates a theme in my overall conclusion on the nature and role of public policy in the Nehru era, there is a need to distinguish the economic policy of this period from what was yet to emerge. What we now recognize as the major distinguishing features of the policy regime of India since Independence were to come later. I have in mind the Monopolies and Restrictive Trade Practices (MRTP) Act and the Foreign Exchange Regulation Act (FERA), an astronomical marginal rate of taxation of income, the nationalisation of banks and the legislation ${ }^{100}$ that has come to be known as 'labour laws' all together providing a happy hunting ground and a rich source of rent for an increasingly unregulated bureacracy. Most of this has been draconian and little of it has served the upliftment of India's poor, but it is worth recalling that all of this had come after the death of Nehru. Indeed, that some of it was to follow that event very closely is itself indicative of the Nehru's own attitude to many of these interventions.

The second angle from which the Nehruvian strategy is criticized targets what we would more readily recognize as an economic model than merely a contingent loss of economic freedoms. This critique is a little more fleshed out than the first, and based a little more on empirical

99. See Chibber (2003).

100. Of course, legislation governing work and employment in the factories date from the colonial era. 
reasoning, though I shall have occasion to point out that this can lead the argument to unexpected conclusions including that of validating the choice of model in the first place. It proceeds by arguing that the model of import-subtituting industrialization (ISI) that India had followed was unlikely to have done any better that it actually did in the long run, and that India's mistake was to have chosen this model over one of greater outward orientation with a central role for trade. Even though the critique of ISI was that protection induced high-cost production this by itself was not enough to disqualify such a model from the perspective of growth, for these is no particular reason to insist that growth will be necessarily slower within such a system. So reference was now made to historical experience. By the late seventies the larger and more prominent developing economies that had adopted ISI had begun to appear stuck in a groove of slow growth. On the other hand, the economies of East Asia, namely Korea, Taiwan, Hong Kong, Singapore had all arrived on the global stage as leading exporters and were also the fastest growing economies of the world. From this was born the idea of an export-led growth, and the ISI model was written off completely as a non-starter. Proceeding from the poor record of exports of the countries, India included, that had promoted ISI it was concluded that interventionism was responsible for the disappointing outcome. As I shall demonstrate, this conclusion was somewhat premature. Answers to two issues need to be sorted out first. These pertain to competitiveness and causality. While it is no more than a matter of accounting that fast-growing exports will raise the rate of growth of an economy, it has been recognised that the causality between growth and exports is not strictly of the kind usually presumed by arguments for an export-led growth. For instance, where dynamic economies of scale are to be reaped a faster economy-wide growth leads to faster productivity growth in all sectors and this enhances the international competitiveness of an economy's exports. Now the causality is directly from growth to exports and not from exports to growth. However, not all cases of international competitiveness can be 
attained thus, and for many of the far-eastern economies the domestic market was much too small to depend upon for faster growth to bring abut a greater international competitiveness. Here a competitiveness was developed, and the question remains how. While protection is fundamental, the rationale being no more than the century-old 'infant industry' argument of List, it is clear that it is far from sufficient to explain the attainment of this competitiveness. The work of Alice Amsden has helped us understand how this has been done in these other economies of the Far East which unlike Japan in the interwar years or China today actually entered markets for fairly sophisticated manufactures especially electronics. Combined with the work of Wade this has led to a "significant re-thinking in development studies" 101 of the strategy of growth to be pursued by the underdeveloped economies of he world. Their work has conclusively established the role of ISI in general and intervention in particular as having laid the base of the East Asian success. No longer are we satisfied with hoary accounts of free trade, export-led growth and merely 'market-friendly' governments that only dealt at arms length from private agents.

Bruce Scott (1997) has investigated the historical basis for the claim that the successful economies of the world had abjured intervention, or state directedness, and adhered to free trade. Scott has studied two historical episodes, one less often encountered in development economics today. The first episode is that of the well-known East Asian experience, and his comment is as follows: "Taiwan and South Korea .... now have relatively free economies. In earlier decades, these countries did have some economic freedoms, notably in product markets. But both were authoritarian regimes with non-transparent controls aimed at simultaneously promoting exports and restricting foreign entry into their economies. The state-owned banking system in South Korea allowed the chaebol conglomerates to develop rapidly with little retained equity,

101. Chibber (2003). 
much like the Japanese keiretsu in the early 1950s. South Korea's leaders chose to develop the economy by concentrating their efforts on a small number of large companies, which they protected by eliminating the market for corporate control. They also established labour laws that all but eliminated workers' ability to bargain collectively, thereby ensuring that companies would have the lion's share of income in order to promote development. Taiwan used purchasing policies of state-owned enterprises for similar purposes. Only in recent years, as their economies achieved a high degree of success, have Taiwan's and South Korea's governments begun to relax their grip."102 Though accounts of the East Asian experience, including of the associated role of government, abound ${ }^{103} \mathrm{I}$ have chosen this one for its particular clarity. But Scott's contribution to the debate on 'economic freedom' was to come in taking on the argument in the context of the historical experience of the first industrial country, referred to in the context as Great Britain. Addressing the claim that it had gained economic supremacy in the $19^{\text {th }}$ century when it moved to a free trade regime he has argued: "But its rise took place mainly in the previous century, when in competition with France and the Netherlands, it relied on a protectionist policy of trade promotion and on forced mobilization of resources. Great Britain dismantled its trade regime after it became the undisputed economic, financial, and industrial leader of the world, not before. Under its new, freer policies it began its relative economic decline and was slow to take advantage of the newer industries based on electrical and chemical engineering. For all its freedoms, it had performed below average for industrial countries for more than a century - and especially since World War II - as its incomes have fallen below those in most of the rest of Western Europe.

It is true that Great Britain began its initial rise to supremacy by freeing up its internal market, a step it took while other sizeable countries

102. Scott (1997), p. 159.

103. See in particular Chang (2003). 
were divided into regions with their own trade barriers. The Great Britain of the $18^{\text {th }}$ century had the largest domestic market in Europe even though it population was less than half of France's, and that market encouraged a great deal of economic innovation and resourcefulness. The United States followed the same pattern during its ascendance: it combined a free domestic market with sizeable tariff barriers until after World War II. Indeed all the leading industrial powers developed as protectionist regimes in the $19^{\text {th }}$ century, whereas countries such as India and Portugal, following free trade regimes, found themselves stripped of industry." 104

However, it is Scott's observation on contemporary China that serves most to query the privileging of economic freedom as a driver of economic growth, and that has the greatest potential of sorting out ideological predilection from economics. Scott observes: "With almost twenty consecutive years of growth exceeding 5 percent per capita per year, China already seems to be demonstrating that the lives of 1.2 billion people can be radically improved in an environment that sharply limits freedom." 105 In the context of the debate on the best 'model' for growth this example has an interesting implication. It shows that selecting the model that ought to have been chosen in the past using the criterion of current growth rates can be treacherous for those committed to a narrow vision of economic freedom. For, if, on the basis of current growth rates, China's is to judged the right choice of development model it must logically follow that India's mistake was not in having chosen the Mahalanobis model but in not taking it far enough in investing in heavy industry and sealing itself off from the rest of the world in the 1950s. Indeed in some remarkably prescient writing done over three decades ago, at a time when China's rise to economic power status was yet to have been imagined, Byres and Nolan (1976) had concluded that: “... China has progressed towards industrialisation at a faster rate than India

104. Ibid, p. 159.

105. Ibid., p. 159. 
and appears to be poised for an even faster pace of industrial advance than India in the future.” The basis for their prognosis is: “... the greater emphasis given by China to the development of 'key' industries places her in a better position for future economic development, since it has freed her to a greater extent than India from the foreign exchange constraint over the rate of investment and growth. China now appears to have a significantly greater capability than India to produce domestically the 'producer' goods that are the physical wherewithal of investment." Interestingly, in the context of the general distrust of planning as an unneccesary interference in the market mechanism Byres and Nolan state that China's superior performance is due to the "quality and effectiveness of planning" in that country compared with that attempted in India. It is possible to recognise their forecast as an instance of extraordinary economic intuition even as one may disagree outright with their assertion that China had attained whatever it had "without the terrible cost in human suffering" that has characterised the Indian experience. Though weighingup deprivations one against the other is like comparing apples and oranges, one might yet argue that it is not credible to assert that the costs of political repression, and the alleged death by starvation following economic adventurism, in China amount to less than that of the chronic hunger in India. Silence on the political repression would have been inexcusable even at a time when information was scarce and the political leadership had yet to start implementing the 'one child per couple' policy by forcing third-trimester abortions for accounts of the excesses of the Cultural Revolution had begun to filter through by the early seventies.

What emerges from our discussion can be concisely summarised thus: While it can hardly be denied that markets are fundamental to sustained growth it would be naïve to dismiss governments as dispensable to the outcome. Indeed that would be a misreading of a by now richly documented history of economic growth in diverse settings and across centuries. Even without insisting that government is the driver of growth, diverse experiences of economic growth and development show us that 
government is an economic driver in the sense that its actions can have majorly beneficial consequences.

With so much historical experience of success using a model of ISI it is difficult to walk away insisting that the choice of model per se explains India's relatively slow growth for about two decades from the mid-sixties. The answer must be sought in the domestic political economy, the balance of economic and political forces that determine economic outcomes, and the nature of the Indian state ${ }^{106}$. Following the work of Wade (1990) on Korea we are able to see that in India the government singularly failed to govern the market. Nevertheless, as I have shown, the record growth in the Nehru era was far from what tends to get assumed or suggested.

While the discussion in this section may have served to dispel the perception that policy in the Nehru era had neglected the crucial role of agriculture or even the savings potential of the public sector enterprises and that it was based on an economic model that stood no chance of success, there is one area that appears to have been neglected very severely then. And this is primary education. Rare are the interventions from contemporary Indian economists on the relevance of primary education, but there is a particularly forceful one by Krishnamurti ${ }^{107}$, an economist then with the Bombay School. In 1955, within months of the publication of the 'Recommendation for the Second Five-Year Plan' brought out by the Planning Commission, Krishnamurti was writing “... how absurdly low are the sums allotted for education in the Mahalanobis Plan.", speaking of it as being lop-sided, with little importance given to education and other social services, and calling for a re-allocation to expenditure on this account from the outlay on heavy industries. More important are

106 Such explanations have been provided by Chibber (2003) and Kohli (2004), respectively.

107 See 'Krishnamurti' in Balasubramanyan (2001). I am indebted to Ramachandra Guha who brought this extraordinary document to my attention. 
Krishnamurti's reasons for a greater expenditure on education and interesting is his explanation for why it is so low. "A concerted effort to educate the mass of the population, specially in the rural areas, would undoubtedly have far-reaching benefits of a cumulative expansionist character. This would greatly lighten the task of the government in bringing about rapid economic development." Pointing to the government's lack of even-handedness in dealing with education in comparison with "heavy industries or river valley projects" for which it was willing to adopt deficit financing, he speculates whether this has to do with the fact that "being brought up in the traditions of mid-Victorian finance" it continues to "apply the calculus of the private grocery merchant to a matter like education."108

Interestingly, in all the counterfactual scenarios that are sketched for India it is openness to trade that tends to get emphasised, the implicit suggestion being that the possibilities of trade were neglected. There may well be a point to this observation, at least surely for the period starting the early sixties. However, the absence of primary education from these exercises of counterfactual analysis is striking. One cannot overlook the likelihood that the very face of India, not to mention the rate of growth of output via human capital accretion, may have been vastly different had much more attention been paid to primary education at the very outset. As this study is also an evaluation of the contribution of Nehru to the growth and transformation of India, I am reminded of the comment made to me by a civil servant in Bangalore that the man whose birthday is celebrated as Children's Day in India had actually managed to do very little for her very young. Cruel as it may sound, and appearing as outrageous given Nehru's known empathy with children, the verdict is very close for it is indeed correct that primary education was severely neglected in the Nehru era. It is of course technically true that, given the constitutional distribution of powers in India, Education

108. All quotations are from 'Krishnamurti' in Balasubramanyan (2001). 
- being a 'State Subject' - was then at least partially a responsibility of the states, but this does not absolve the policy maker of the Nehru era of a grave error of judgment regarding the factors that drive growth, leave alone development. Of course, even into the twentyfirst century, we continue to neglect the continued neglect of primary education.

\section{Conclusion}

The public policy of the Nehru era had set in motion a more or less stagnant colonial economy. A proliferating bureaucracy, corruption, closedness to foreign capital and the consequent technological backwardness in production, the lack of competition and the consequent shoddiness of the consumer goods, an unaccountable public sector and the consequent low productivity all, perhaps unintendedly but surely tragically, 'came along', so to speak. But it cannot be denied that the economy had been got moving, and in any case specific policies were open to correction. A course-correction could well have been applied, but it was not. Instead, after the death of Nehru, was witnessed what has been described as a 'lurch to the left' characterised by increasing trade and industrial policy controls and at times reckless expansion of publicsector employment. What precise role these policies had in shoring up the post-Nehru political establishment remains to be analysed. To attempt to answer this would take me far from the objective of this essay, but there exist accounts by political scientists ${ }^{109}$. However, one thing is clear. Many of these policies were at a tangent from those of the Nehru era, notably the deteriorating performance of the public sector and the use of public monies to buy out economic disaffection with subsidies. This came to be termed 'Nehruvian socialism' even though the elimination of economic waste, unaccountable governance and inefficiency of resource use were the very arguments for socialism in the first place, and not just in India. But more to the point, no matter that all of it bore

109. See Hankla (2006). For a less theory-laden but historically richer, in that it is related to specific events, account see Chandra, Mukherjee and Mukherjee (2000). 
no resemblance to what had been practiced in the Nehru era. It's consequences were serious for India. As Chandra, Mukherjee and Mukherjee (2000) have commented: "The controls, restrictions, interventions .... were paradoxically often resorted to in the name of introducing 'socialist' principles and equity but actually ended up building a distorted, backward capitalism ....."110 From the point of view of understanding the past, Desai's comment "Today when people criticise the Nehruvian model, little do they know that it began with the daughter, and not the man himself." "111 is apt. While it was a disappointing end to a high-minded journey, it is important to place the outcome in proper perspective when we evaluate the Nehru-Mahalanobis Strategy.

I would hope that this paper restores some perspective to the recent economic history of India. The Nehru era witnessed the recovery of India and the igniting of a growth process that has remained undimmed for over five decades, during which time the economy has been hastening slowly. The repeated acceleration of the growth rate implies that drawing a likeness between the policies of the Nehru era and the Soviet Union is false as growth in India has been sustained in a way that it was not in the Former Soviet Union. Actually, India's growth rate has accelerated and it may be suggested that this is not incompatible with the NehruMahalanobis Strategy.Within the recovery engineered I have flagged two specific achievements of the Nehru era: the quite spectacular transformation of agriculture as reflected in the acceleration of production and the unprecedented mobilisation of resources by the Indian state as reflected in the hike in public investment. There have been errors of commission, such as the proliferation of an unregulated economic bureaucracy, and of omission, such as the gross neglect of primary education. But there have been four decades after Nehru to correct these.

110 Chandra, Mukherjee and Mukherjee (2000), p. 359.

111 Desai (2007), p. 40. See also the distinction 'Nehru versus Nehruites' drawn by Dhar (1989). 
To suggest that this is due to a 'lock-in' 112 effect of the Nehruvian strategy and that nothing could have been done to alter the situation is only to confirm that we have not understood the lessons of our recent past.

This paper has studied economic growth in the Nehru era. The picture that has emerged has a bearing on two unrelated questions. The first is a generic one of perennial interest to economists, the role of government in economic growth. The second is the historical role of Jawaharlal Nehru with respect to the Indian economy in general, and long-term growth in particular. I deal with these together in what remains of this concluding section.

Even though I have not focused on the particular role of Jawaharlal Nehru in the formulation and implementation of the economic policy of his time, I have here, however, presented an account of his views on the economy including, to an extent, of their evolution. Arguably, no Indian leader since at the helm of this country has been as crucial to the navigation of its economy. The economic record of this time serves as one important indicator of the effectiveness of his role. Under Jawaharlal Nehru the Indian economy had been transformed from a colonial enclave to one with at least some of the prerequisites for sustained long-term growth while at the same time maintaining an autonomy from the superpowers vying for influence on a newly independent sub-continent. As a particular icon of this transformation we may consider the rate of growth achieved in the Nehru years. I have provided both historical and comparative perspective on this variable and argued that the achievement was indeed remarkable. The framework within which it had been achieved reflects upon today's thinking on the ideal economic architecture for growth. Central to this purported ideal is the construct of economic freedom, defined as absence of restraint. Considered 'Economics' since the implosion of the Soviet Union, this idea is sharply at odds with the

112. Chibber (2003). 
recent history of China where the longest ever recorded boom is occurring in an environment that severely ${ }^{113}$ restricts freedoms. While the situation in the Nehru era was a far cry from contemporary China, both in terms of economic and political freedoms, the growth performance of that period engineered almost entirely by the state is a serious challenge to the thinking on growth encapsulated in the Washington Consensus, a recipe for prosperity highly influential in the nineties but by now ${ }^{114}$ under challenge.

By implication, this study has also provided an evaluation of the historical role of Jawaharlal Nehru albeit in a limited sphere, the economy. As I have mentioned, this exercise is not itself of only limited interest though, as even the most authoritative appraisals of the man tend to dwell less on his role as an economic architect. But I am aware of my appraisal being radically at odds with broader evaluations of the man from across the political spectrum. I shall present the briefest possible accounts of what I consider a representative set. The first is that of Hiren Mukerjee, a close contemporary of Nehru's, a lawyer and a member of the Communist Party of India. Author of an affectionate portrait of Nehru as a 'gentle colossus', published in the year of Nehru's death, Mukerjee had had the following to say: "But for him, India would have felt much less the winds of change that had been blowing over the world; he made us aware of them and also more receptive. Yet he failed his people in so far as he could not adequately execute the great mandate he had from them because he just was not relentless enough. He was our beautiful but ineffectual angel, beating his beautiful wings largely in vain."115 The second view of Nehru that I wish to present here comes from India's far right. The RSS leader K.S. Sudarshan speaking in New Jersey in

113. Labour has limited rights of geographical mobility and none of trade-union mobilisation in China.

114. See Rodrik (2006).

115. Mukerjee (1964), p. 223-4. 
2005 has said: "We hoped that things would change after the (sic) Indian Independence .... but that did not happen. Nehru was the last Britisher to have ruled India, therefore nothing at all changed." 116 While Sudarshan's concerns in the speech are mostly focused on culture, it does suggest that little changed in India under Nehru. Only rank ignorance would lead one to equate the colonial and early post-colonial economies of India. Finally, I quote someone who by his sympathies and intellectual reach would be deemed a 'global Indian'. An enthusiast for the reforms of 1991, some have seen him as a spokesman for India's corporate sector, but it is apparent from his writings that Gurcharan Das is nevertheless deeply concerned of the well-being of his compatriots. He has argued that: “... Jawaharlal Nehru and his planners attempted an industrial revolution through the agency of the state. They did not trust the private entrepreneurs, so they made the state the entrepreneur. Not surprisingly, they failed, and India is still paying a high price for their follies." $117 \mathrm{We}$ have here a conspectus of views on Jawaharlal Nehru covering a wide angle. I believe that in the light of my account of the growth of the Indian economy in the Nehru era they appear without credibility. On the other hand, the estimate of Nehru by his partner in the charting of India's economic journey compels our attention. For a statistician, likely to have been alert to the need for weighing-up of probabilities, Mahalanobis's forecast for the economy, made in the late fifties, is markedly free of confidence intervals! He had remarked: "One thing can be said with complete certainty. Whether there is a smooth transition or whether India has to pass through storms on her way to progress, it will be impossible to go back to a stagnant economy. Through his leadership, he has brought about profound changes in social and productive forces which will continue to influence the course of events in India in the most decisive way." 118 This forecast has accredited itself. It must encourage us to begin

116. Sudarshan (2005).

117. Das (2000).

118. Mahalanobis (1960), p. 563. 
to view the recovery achieved by the policies of the period as a bridgehead to the higher growth rates that have followed. The shibboleth 'Hindu rate of growth', presumably a broad-brush description of movement in this period, manages to obscure the extraordinary economic dynamics of the Nehru era.

Pulapre Balakrishnan is Senior Fellow, Nehru Memorial Museum and Library, New Delhi. He is Honorary Visiting Professor, Centre for Development Studies, Trivandrum.

e-mail contact: pbkrishnan @yahoo.com 


\section{References}

AM (1964) "We the people", 'Economic Weekly', 26: 1195-8.

Amsden, A. (2001) 'The Rise of the 'Rest': Challenges to the West from Late Industrialising Economies', New York: Oxford University Press.

Balakrishnan, P., and M. Parameswaran (2007) "Understanding economic growth in India, A prerequisite", 'Economic and Political Weekly', July 14-20.

Balasubramanyan, V.N. (2001), 'Conversations With Indian Economists', New Delhi: Macmillan.

Bagchi, A. and P. Nayak (1994) "Public finance and the planning process", in A. Bagchi and N. Stern, 'Tax Policy in Developing Countries', Delhi: Oxford University Press.

Bagchi, A. (1972), 'PrivateInvestment in India, 1900-1939', Cambridge: Cambridge University Press.

Bhagwati, J. (1956) "Deficit financing and economic development", 'Indian Economic Review', 2: 40-60.

Bhagwati, J. and P. Desai (1970) 'India, Planning for Industrialisation', Delhi: Oxford University Press.

Bhagwati, J. (1998) "India's economic reforms: Dismantling the machine for going backwards", 'Vikalpa', 23: 5-7.

Bhat, P.N.M. (2001) ‘A demographic bonus for India?’, Keynote address at the symposium "Our common future", Population Research Centre, University of Groningen, 22 November.

Blyn, G. (1966) 'Agricultural Trends in India, 1891-1947: Output, Availability and Productivity', Philadelphia: University of Pennsylvania Press.

Byres, T. and P. Nolan (1976) "Inequality: India and China compared", Milton Keynes: The Open University Press. 
Chakravarty, S. (1987) 'Development Planning: The Indian Experience', Delhi: Oxford University Press.

Chandra, B., M. Mukherjee and A. Mukherjee (2000) 'India After Independence 1947-2000’, New Delhi: Penguin, first published in 1999 by Viking.

Chang, H-J. (2003), "The East Asian Development Experience”, in Ha Joon Chang (ed.), 'Rethinking Development Economics', London: Anthem Press.

Chibber, V. (2003) 'Locked in place: State-building and late industrialization in India', Princeton: Princeton University Press.

Castells, M. (2000) 'The Information Age: Economy, Society and Culture', Volume 3: The "End of the Millenium", Oxford: Blackwell

Das, G. (2000) 'India Unbound: From Independence to the Global Information Age', New Delhi: Penguin.

DeLong, B. (2004) "India since Independence: An analytic growth narrative", in D. Rodrik (ed.) 'In Search of Prosperity: Analytic Narratives on Economic Growth', Princeton: Princeton University Press.

Desai, M. (1998) “Was there an alternative to Mahalanobis?”, in 'India's Economic Reforms and Development: Essays for Manmohan Singh', by Isher Judge Ahluwalia and I.M.D. Little, Delhi: OUP.

Desai, M. (2007) "Our economic growth: 1947-2000”, in 'India 60', IIC Review, Winter 2006-Spring 2007.

Dhar, P.N. (2003) "Nehru versus Nehruites", in 'The evolution of economic policy in India', Delhi: Oxford University Press, first published in 1989.

Gopal, S. (1975, 1979, 1984), 'Jawaharlal Nehru: A Biography', in 3 volumes, Delhi: Oxford University Press. 
Hankla, C.R. (2006) "Party linkages and economic policy: An examination of Indira Gandhi's India”, 'Business and Politics', http://www.bepress.com/bap/vol8/iss3/art4.

Hatekar N. and A. Dongre (2005), "Structural breaks in India's growth: Revisiting the debate with longer perspective", 'Economic and Political Weekly', April 2: 1432-5.

Joshi, P.C. (1979) "Dimensions of agricultural planning: Reflections on the Mahalanobis approach”, 'Man and Development', 4: 9-31.

Kalecki, M. (1993) "Observations on social and economic aspects of "Intermediate Regimes"”, in 'Collected Works of Michal Kalecki, volume 5: The Developing Economies’, Oxford: The Clarendon Press. First published in 1964.

Kohli, A. (2004) 'State-directed development: Political power and industrialization in the global periphery', Cambridge: Cambridge University Press.

Krishna, R. (1982) “Assessing India's economic development”, 'Mainstream', October 25.

Krishna, R. (1988) "Ideology and economic policy”, 'Indian Economic Review', 23: 1-26.

Lal, D. (1999) 'Unfinished business: India in the World Economy', Delhi: Oxford University Press.

Maddison, A. (1995) 'Monitoring the World Economy 1820-1992', Paris: OECD Development Centre.

Mahalanobis, P.C. (1955), "The approach of operational research to planning in India”, 'Sankhya:The Indian Journal of Statistics', parts $1 \& 2$.

Mahalanobis, P.C. (1960), ‘Talks on planning', Calcutta: Indian Statistical Institute.

Malhotra, I. (2007) “Nehru's luminous legacy”, in 'India 60', IIC Review, Winter 2006-Spring 2007. 
Mathrubhumi (2007) Vikassanathine Panam Ilya, 'There is no money for development', January 1.

Milanovic, B. (2003) "The two faces of globalization", "World Development', 31: 667-83.

Mishra, V.N. (2004) 'The State of the Indian Farmer: A Millennium Study', Volume 15, 'Terms of Trade', New Delhi: Academic Foundation, Ministry of Agriculure.

Mohan, R. and V. Aggarwal (1990) "Commands and controls: Planning for Indian industrial development, 1951-1990”, 'Journal of Comparative Economics', 14: 681-712.

Mokyr, J. (2005) “The intellectual origins of the Industrial Revolution", 'The Journal of Economic History', 65: 285-351.

Mukerjee, H. (1964) 'The gentle colossus: A study of Jawaharlal Nehru', Calcutta: Manisha Granthalaya Private Limited.

Myrdal, G. (1957) 'Economic theory and the underdeveloped regions', London: Methuen.

Panagariya, A. (2005) 'The triumph of India's market reforms: The record of the 1980s and 1990s', Policy Analysis 554, Washington, D.C.: The Cato Institute.

Parameswaran, M. (2007) 'Growth transitions in twentieth-century India', Centre for Development studies, Thiruvananthapuram.

Planning Commission (1956), 'Recommendation for the Second FiveYear Plan', New Delhi.

Price, R.B. (1967) "Ideology and Indian Planning”, 'American Journal of Economics and Sociology', 26: 47-64.

Price, R.B. (1968) "Reply: "On 'Ideology and Indian Planning,"', 'American Journal of Economics and Sociology', 27: 217-18.

Raj, K.N. (1954) 'Definition and measurement of deficit financing", 'Indian Economic Review', 2: 34-51.

Raj, K.N. (1965), 'Indian Economic Growth: Performance and Prospects', New Delhi: Allied Publishers. 
Raj, K.N. (1967) 'India, Pakistan and China: Economic Growth and Outlook', Bombay: Allied.

Rao, M.G. and T.K. Sen (1995) "Public finance and economic development: Lessons from India”, 'Asia Pacific Development Journal', 2: 25-44.

Rao, S.K. (2004) "Indian development strategies and policies, 194570", paper presented at the Wassenar Conference on 'The development of development policies: Theories, actors and structures, 1945-1970', Hyderabad: Administrative Staff College of India.

Rao, V.K.R.V. (1952), "Investment, income and the multiplier in an underdeveloped economy”, 'Indian Economic Review, 1: 55-67.

Rao, V.K.R.V. (1971) ‘The Nehru Legacy’, Bombay: Popular Prakashan.

Ray, D. (1998) 'Development Economics', Delhi: Oxford University Press.

Reddy, B.V.R. Mohan (2006) "The new high-growth sector", 'The Hindu', August 24.

Romer, P. (1986) 'Increasing returns and long-run growth", 'Journal of Political Economy', 92: 1002-37.

Rodrik, D. (2006) “Goodbye Washington Consensus, Hello Washington Confusion? A Review of the World Bank's Economic Growth in the 1990s: Learning from a Decade of Reform", 'Journal ofEconomic Literature', 44, December.

Rosenstein-Rodan, P.N. (1943) "Problems of industrialisation of Eastern and South Eastern Europe”, 'The Economic Journal', 53: 202-211.

Scott, B.R. (1997) "How do economies grow?", 'Harvard Business Review', May-June: 156-164.

Singh, M. (2004) 'Prime Minister's Address', All-India Conference of Lokayuktas and Uplokayuktas at Dehradun, September 29, Press Release of the Government of India, http://pib.nic.in/release. 
Sivasubramonian, S. (2000), 'The National Income of India in the Twentieth Century', Delhi: OUP.

Shenoy, B.R. (1955) "A Note of Dissent on the Memorandum of the Panel of Economists"', 'Basic Considerations Relating to the Plan Frame, A Memorandum prepared by the Panel of Economists', New Delhi: Planning Commission.

Srinivasan, T.N. (1996) "Professor Mahalanobis and economics", in A. Rudra (ed.) 'P.C. Mahalanobis: A Biography, Delhi: Oxford University Press.

Sudarshan, K. S. (2005) 'Hindu spirituality should be spread in America', Speech at Dharma Summit, New Jersey, August 13-15, http:// www.theuniversalwisdom.org/category/speakers/k-s-sudarshan.

Vasudevan, A. (1968) "On "Ideology and Indian Planning"”, 'American Journal of Economics and Sociology', 27: 214-16.

Visvesvaraya, M. (1936) 'Planned Economy for India', second edition, Bangalore: The Bangalore Press. First published in 1934.

Wade, R.H. (1990) 'Governing the Market: Economic Theory and the Role of Government in East Asian Industrialisation', Princeton: Princeton University Press.

Williamson, J. (1990) "What Washington means by policy reform", in 'Latin American Adjustment: How Much has Happened?', edited by John Williamson, Washington: Institute for International Economics.

Winchester, S. and R. Winchester (2004) "Calcutta: A Brief History”, in 'Simon Winchester's Calcutta', Footscray, Victoria, Australia: Lonely Planet Publications.

Zachariah, B. (2004) 'Nehru', London: Routledge. 


\section{CENTRE FOR DEVELOPMENT STUDIES LIST OF WORKING PAPERS \\ [New Series]}

The Working Paper Series was initiated in 1971. A new series was started in 1996 from WP. 270 onwards. Working papers beginning from 279 can be downloaded from the Centre's website (www.cds.edu)

W.P. 390 SUNIL MANI, The Growth Performance of India's Telecommunications Services Industry, 1991-2006 Can it Lead to the Emergence of a Domestic Manufacturing Hub? September 2007

W.P. 389 K. J. JOSEPH, VINOJ ABRAHAM, Information Technology and Productivity: Evidence from India's Manufacturing Sector. September 2007

W.P. 388 HRUSHIKESH MALLICK, Does Energy Consumption Fuel Economic Growth In India? September 2007

W.P. 387 D. SHYJAN, Public Investment and Agricultural Productivity: A State-wise Analysis of Foodgrains in India. July 2007

W.P. 386 J. DEVIKA, 'A People United in Development': Developmentalism in Modern Malayalee Identity. June 2007.

W.P. 385 M. PARAMESWARAN, International Trade, $R \& D$ Spillovers and Productivity: Evidence from Indian Manufacturing Industry. June 2007.

W.P. 384 K. C. ZACHARIAH, S. IRUDAYA RAJAN Economic and Social Dynamics of Migration in Kerala, 1999-2004 Analysis of Panel Data. May 2007.

W.P. 383 SAIKAT SINHA ROY Demand and Supply Factors in the Determination or India's Disaggregated Manufactured Exports : A Simultaneous Error-Correction Approach. May 2007

W.P. 382 SUNIL MANI The Sectoral System of Innovation of Indian pharmaceutical industry. September 2006

W.P. 381 K. J. JOSEPH, GOVINDAN PARAYIL Trade Liberalization and Digital Divide: An Analysis of the Information Technology Agreement of WTO. July 2006. 
W.P. 380 RUDRA NARAYAN MISHRA Dynamics of Caste-based Deprivation in Child Under-nutrition in India. July 2006.

W.P. 379 P.L.BEENA, Limits to Universal Trade Liberalisation: The Contemporary Scenario for Textiles \& Clothing Sector in South Asia. March 2006.

W.P. 378 K.N. NAIR, VINEETHA MENON, Lease Farming in Kerala: Findings from Micro Level Studies. November 2005.

W.P. 377 NANDANA BARUAH, Anti Dumping Duty as a Measure of Contingent Protection: An Analysis of Indian Experience. October 2005.

W.P. 376 P. MOHANAN PILLAI, N. SHANTA Long Term Trends in the Growth and Structure of the Net State Domestic Product in Kerala. October 2005.

W.P. 375 R. MOHAN, D. SHYJAN Taxing Powers and Developmental Role of the Indian States: A Study with reference to Kerala. August 2005.

W.P. 374 K. C. ZACHARIAH, S. IRUDAYA RAJAN. Unemployment in Kerala at the Turn of the Century: Insights from CDS Gulf Migration Studies. August 2005.

W.P. 373 SUNIL MANI, The Dragon vs. The Elephant Comparative Analysis of Innovation Capability in the Telecommunications Equipment Industry in China and India. July 2005

W.P. 372 MOTKURI VENKATANARAYANA On The Non-Random Distribution of Educational Deprivation of Children in India. July 2005

W.P. 371 DIBYENDU S. MAITI Organisational Morphology of Rural Industries in Liberalised India: A Study of West Bengal. June 2005

W.P. 370 SUNIL MANI, Keeping Pace with Globalisation Innovation Capability in Korea's Telecommunications Equipment Industry. March 2005.

W.P. 369 V.R. PRABHAKARAN NAIR, Determinants of Fixed Investment: A Study of Indian Private Corporate Manufacturing Sector. March 2005.

W.P. 368 J. DEVIKA, Modernity with Democracy? : Gender and Governance in the People's Planning Campaign, Keralam. February 2005 
W.P. 367 VINEETHA MENON, ANTONYTO PAUL, K N NAIR Dynamics of Irrigation Institutions: Case study of a Village Panchayat in Kerala. February 2005

W.P. 366 VIJAYAMOHANAN PILLAI N. Causality and Error Correction in Markov Chain: Inflation in India Revisited. December 2004.

W.P. 365 R. MOHAN. Central Finances in India - Alternative to Procrustean Fiscal Correction. November 2004.

W.P. 364 SUNIL MANI. Coping with Globalisation Public $R \& D$ Projects in Telecommunications Technologies in Developing Countries. November 2004.

W.P.363 K C ZACHARIAH, S IRUDAYA RAJAN. Gulf Revisited Economic Consequences of Emigration From Kerala, Emigration and Unemployment. September 2004.

W.P.362 M. VENKATANARAYANA. Educational Deprivation of Children in Andhra Pradesh, Levels and Trends, Disparities and Associative Factors. August 2004.

W.P.361 K.P. KANNAN, VIJAYAMOHANAN PILLAI N. Development as a Right to Freedom: An Interpretation of the Kerala Model. August 2004.

W.P. 360 VIJAYAMOHANAN PILLAI N. CES Function, Generalised Mean and Human Poverty Index: Exploring Some Links. July 2004.

W.P. 359 PRAVEENA KODOTH, Shifting the Ground of Fatherhood: Matriliny, Men and Marriage in Early Twentieth Century Malabar. May 2004.

W.P. 358 MRIDUL EAPEN. Women and Work Mobility: Some Disquieting Evidences from the Indian Data. May 2004.

W.P. 357 K. RAVI RAMAN. The Asian Development Bank Loan for Kerala (India): The Adverse Implications and Search for Alternatives, March 2004.

W.P. 356 VIJAYAMOHANAN PILLAI N. Liberalisation of Rural Poverty: The Indian Experience, March 2004.

W.P. 355 P.L.BEENA Towards Understanding the Merger-Wave in the Indian Corporate Sector: A Comparative Perspective, January 2004.

W.P. 354 K.P. KANNAN AND R. MOHAN India's Twelfth Finance Commission A View from Kerala, December 2003. 
W.P. 353 K.N. HARILAL AND P.L. BEENA The WTO Agreement on Rules of Origin Implications for South Asia, December 2003.

W.P. 352 K. PUSHPANGADAN Drinking Water and Well-being In India: Data Envelopment Analysis, October 2003.

W.P. 351 INDRANI CHAKRABORTY Liberalization of Capital Inflows and the Real Exchange Rate in India : A VAR Analysis, September 2003.

W.P. 350 M.KABIR Beyond Philanthropy: The Rockefeller Foundation's Public Health Intervention in Thiruvithamkoor, 1929-1939, September 2003.

W.P. 349 JOHN KURIEN The Blessing of the Commons : Small-Scale Fisheries, Community Property Rights, and Coastal Natural Assets, August 2003.

W.P. 348 MRIDUL EAPEN, Rural Industrialisation in Kerala: ReExamining the Issue of Rural Growth Linkages, July 2003.

W.P. 347 RAKHE PB, Estimation of Tax Leakage and its Impact on Fiscal Health in Kerala, July 2003.

W.P. 346 VIJAYAMOHANAN PILLAI N, A contribution to Peak load pricing theory and Application. April 2003.

W.P. 345 V.K. RAMACHANDRAN, MADHURA SWAMINATHAN, VIKAS RAWAL Barriers to Expansion of Mass Literacy and Primary Schooling in West Bengal: Study Based on Primary Data from Selected Villages. April 2003.

W.P. 344 PRADEEP KUMAR PANDA Rights-Based Strategies in the Prevention of Domestic Violence, March 2003.

W.P. 343 K. PUSHPANGADAN Remittances, Consumption and Economic growth in Kerala: 1980-2000, March 2003.

W.P. 342 D NARAYANA Why is the Credit-deposit Ratio Low in Kerala? January 2003.

W.P. 341 MRIDUL EAPEN, PRAVEENA KODOTH Family Structure, Women's Education and Work: Re-examining the High Status of Women in Kerala. November 2002.

W.P. 340 J. DEVIKA, Domesticating Malayalees: Family Planning, the Nation and Home-Centered Anxieties in Mid-20 th Century Keralam. October, 2002.

W.P. 339 M PARAMESWARAN, Economic Reforms and Technical Efficiency: Firm Level Evidence from Selected Industries in India. October, 2002. 
W.P. 338 PRAVEENA KODOTH, Framing Custom, Directing Practices: Authority, Property and Matriliny under Colonial Law in Nineteenth Century Malabar, October 2002.

W.P. 337 K.NAVANEETHAM, Age Structural Transition and Economic Growth: Evidence From South and Southeast Asia, August 2002.

W.P. 336 PULAPRE BALAKRISHNAN, K. PUSHPANGADAN, M. SURESH BABU, Trade Liberalisation, Market Power and Scale Efficiency in Indian Industry, August 2002.

W.P. 335 J. DEVIKA, Family Planning as 'Liberation': The Ambiguities of 'Emancipation from Biology' in Keralam July 2002.

W.P. 334 E. ABDUL AZEEZ, Economic Reforms and Industrial Performance an Analysis of Capacity Utilisation in Indian Manufacturing, June 2002.

W.P. 333 K. PUSHPANGADAN Social Returns from Drinking Water, Sanitation and Hygiene Education: A Case Study of Two Coastal Villages in Kerala, May 2002.

W.P. 332 K. P. KANNAN, The Welfare Fund Model of Social Security for Informal Sector Workers: The Kerala Experience. April 2002.

W.P. 331 SURESH BABU, Economic Reforms and Entry Barriers in Indian Manufacturing. April 2002.

W.P. 330 ACHIN CHAKRABORTY, The Rhetoric of Disagreement in Reform Debates April 2002.

W.P. 329 J. DEVIKA, Imagining Women's Social Space in Early Modern Keralam. April 2002.

W.P. 328 K. P. KANNAN, K. S. HARI, Kerala's Gulf Connection Emigration, Remittances and their Macroeconomic Impact 19722000. March 2002.

W.P. 327 K. RAVI RAMAN, Bondage in Freedom, Colonial Plantations in Southern India c. 1797-1947. March 2002.

W.P. 326 K.C. ZACHARIAH, B.A. PRAKASH, S. IRUDAYA RAJAN, Gulf Migration Study : Employment, Wages and Working Conditions of Kerala Emigrants in the United Arab Emirates. March 2002.

W.P. 325 N. VIJAYAMOHANAN PILLAI, Reliability and Rationing cost in a Power System. March 2002. 
W.P. 324 K. P. KANNAN, N. VIJAYAMOHANAN PILlAI, The Aetiology of the Inefficiency Syndrome in the Indian Power Sector Main Issues and Conclusions of a Study. March 2002.

W.P. 323 V. K. RAMACHANDRAN, MADHURA SWAMINATHAN, VIKAS RAWAL, How have Hired Workers Fared? A Case Study of Women Workers from an Indian Village, 1977 to 1999. December 2001.

W.P. 322 K. C. ZACHARIAH, The Syrian Christians of Kerala: Demographic and Socioeconomic Transition in the Twentieth Century, November 2001.

W.P. 321 VEERAMANI C. Analysing Trade Flows and Industrial Structure of India: The Question of Data Harmonisation, November 2001.

W.P. 320 N. VIJAYAMOHANAN PILLAI, K. P. KANNAN, Time and Cost Over-runs of the Power Projects in Kerala, November 2001.

W.P. 319 K. C. ZACHARIAH, P. R. GOPINATHAN NAIR, S. IRUDAYARAJAN Return Emigrants in Kerala: Rehabilitation Problems and Development Potential. October 2001

W.P. 318 JOHN KURIEN, ANTONYTO PAUL Social Security Nets for Marine Fisheries-The growth and Changing Composition of Social Security Programmes in the Fisheries Sector of Kerala State, India. September 2001.

W.P. 317 K. J. JOSEPH, K. N. HARILAL India's IT Export Boom: Challenges Ahead. July 2001.

W.P. 316 K. P. KANNAN, N. VIJAYAMOHANAN PILLAI The Political Economy of Public Utilities: A Study of the Indian Power Sector, June 2001.

W.P. 315 ACHIN CHAKRABORTY The Concept and Measurement of Group Inequality, May 2001.

W.P. 314 U.S.MISHRA, MALA RAMANATHAN Delivery Compli-cations and Determinants of Caesarean Section Rates in India - An Analysis of National Family Health Surveys, 1992-93, March 2001.

W.P. 313 VEERAMANI. C India's Intra-Industry Trade Under Economic Liberalization: Trends and Country Specific Factors, March 2001

W.P. 312 N. VIJAYAMOHANAN PILLAI Electricity Demand Analysis and Forecasting -The Tradition is Questioned, February 2001

W.P. 311 INDRANI CHAKRABORTY Economic Reforms, Capital Inflows and Macro Economic Impact in India, January 2001 
W.P. 310 K. K. SUBRAHMANIAN. E. ABDUL AZEEZ, Industrial Growth In Kerala: Trends And Explanations November 2000

W.P. 309 V. SANTHAKUMAR, ACHIN CHAKRABORTY, Environmental Valuation and its Implications on the Costs and Benefits of a Hydroelectric Project in Kerala, India, November 2000.

W.P. 308 K. P. KANNAN, N . VIJAYAMOHANAN PILLAI, Plight of the Power Sector in India : SEBs and their Saga of Inefficiency November 2000.

W.P. 307 K. NAVANEETHAM, A. DHARMALINGAM, Utilization of Maternal Health Care Services in South India, October 2000.

W.P. 306 S. IRUDAYA RAJAN, Home Away From Home: A Survey of Oldage Homes and inmates in Kerala, August 2000.

W.P. 305 K. N. HARILAL, K.J. JOSEPH, Stagnation and Revival of Kerala Economy: An Open Economy Perspective, August 2000.

W.P. 304 K. P. KANNAN, Food Security in a Regional Perspective; A View from 'Food Deficit' Kerala, July 2000.

W.P. 303 K. C. ZACHARIAH, E. T. MATHEW, S. IRUDAYA RAJAN, Socio-Economic and Demographic Consequenes of Migration in Kerala, May 2000.

W.P. 302 K. PUSHPANGADAN, G. MURUGAN, Gender Bias in a Marginalised Community: A Study of Fisherfolk in Coastal Kerala, May 2000.

W.P. 301 P. L. BEENA An Analysis of Mergers in the Private Corporate Sector in India, March, 2000.

W.P. 300 D. NARAYANA Banking Sector Reforms and the Emerging Inequalities in Commercial Credit Deployment in India, March, 2000.

W.P. 299 JOHN KURIEN Factoring Social and Cultural Dimensions into Food and Livelihood Security Issues of Marine Fisheries; A Case Study of Kerala State, India, February, 2000.

W.P. 298 D. NARAYANA, K. K. HARI KURUP, Decentralisation of the Health Care Sector in Kerala : Some Issues, January, 2000.

W.P. 297 K.C. ZACHARIAH, E. T. MATHEW, S. IRUDAYA RAJAN Impact of Migration on Kerala's Economy and Society, July, 1999.

W.P. 296 P.K. MICHAEL THARAKAN, K. NAVANEETHAM Population Projection and Policy Implications for Education:A Discussion with Reference to Kerala, July, 1999.

W.P. 295 N. SHANTA, J. DENNIS RAJA KUMAR Corporate Statistics: The Missing Numbers, May, 1999. 
W.P. 294 K. P. KANNAN Poverty Alleviation as Advancing Basic Human Capabilities: Kerala's Achievements Compared, May, 1999.

W.P. 293 MRIDUL EAPEN Economic Diversification In Kerala : A Spatial Analysis, April, 1999.

W.P. 292 PRADEEP KUMAR PANDA Poverty and young Women's Employment: Linkages in Kerala, February, 1999.

W.P. 291 P. K. MICHAEL THARAKAN Coffee, Tea or Pepper? Factors Affecting Choice of Crops by Agro-Entrepreneurs in Nineteenth Century South-West India, November 1998.

W.P. 290 CHRISTOPHE Z. GUILMOTO, S. IRUDAYA RAJAN Regional Heterogeneity and Fertility Behaviour in India, November 1998.

W.P. 289 JOHN KURIEN Small Scale Fisheries in the Context of Globalisation, October 1998.

W.P. 288 S. SUDHA, S. IRUDAYA RAJAN Intensifying Masculinity of Sex Ratios in India : New Evidence 1981-1991, May 1998.

W.P. 287 K. PUSHPANGADAN, G. MURUGAN Pricing with Changing Welfare Criterion: An Application of Ramsey-Wilson Model to Urban Water Supply, March 1998.

W.P. 286 ACHIN CHAKRABORTY The Irrelevance of Methodology and the Art of the Possible : Reading Sen and Hirschman, February 1998.

W.P. 285 V. SANTHAKUMAR Inefficiency and Institutional Issues in the Provision of Merit Goods, February 1998.

W.P. 284 K. P. KANNAN Political Economy of Labour and Development in Kerala, January 1998.

W.P. 283 INDRANI CHAKRABORTY Living Standard and Economic Growth: A fresh Look at the Relationship Through the Non-Parametric Approach, October 1997.

W.P. 282 S. IRUDAYA RAJAN, K. C. ZACHARIAH Long Term Implications of Low Fertility in Kerala, October 1997.

W.P. 281 SUNIL MANI Government Intervention in Industrial R \& D, Some Lessons from the International Experience for India, August 1997.

W.P. 280 PRADEEP KUMAR PANDA Female Headship, Poverty and Child Welfare : A Study of Rural Orissa, India, August 1997.

W.P. 279 U.S. MISRA, MALA RAMANATHAN, S. IRUDAYA RAJAN Induced Abortion Potential Among Indian Women, August 1997.

W. P. 278 PRADEEP KUMAR PANDA The Effects of Safe Drinking Water and Sanitation on Diarrhoeal Diseases Among Children in Rural Orissa, May 1997. 
W. P. 277 PRADEEP KUMAR PANDA Living Arrangements of the Elderly in Rural Orissa, May 1997.

W. P. 276 V. SANTHAKUMAR Institutional Lock-in in Natural Resource Management: The Case of Water Resources in Kerala, April 1997.

W.P. 275 G. OMKARNATH Capabilities and the process of Development March 1997.

W.P. 274 K. PUSHPANGADAN, G. MURUGAN User Financing \& Collective action: Relevance sustainable Rural water supply in India. March 1997.

W.P. 273 ROBERT E. EVENSON, K.J. JOSEPH Foreign Technology Licensing in Indian Industry : An econometric analysis of the choice of partners, terms of contract and the effect on licensees' performance March 1997.

W.P. 272 SUNIL MANI Divestment and Public Sector Enterprise Reforms, Indian Experience Since 1991 February 1997.

W.P. 271 SRIJIT MISHRA Production and Grain Drain in two inland Regions of Orissa December 1996.

W.P. 270 ACHIN CHAKRABORTY On the Possibility of a Weighting System for Functionings December 1996. 


\section{Books Published by the CDS}

Biodiversity, Sustainable Development and Economic Analysis

J. Hans B. Opschoor

CDS, 2004, Rs. 100/\$11

Plight of the Power Sector in India: Inefficiency, Reform and Political Economy

K.P. Kannan and N. Vijayamohanan Pillai

CDS, 2002, Rs. 400/\$40

Kerala's Gulf Connection: CDS Studies on International Labour Migration from Kerala State in India

K.C. Zachariah, K. P. Kannan, S. Irudaya Rajan (eds)

CDS, 2002, pp 232, Hardcover, Rs. 250/\$25

Performance of Industrial Clusters: A Comparative Study of Pump Manufacturing Cluster in Coimbatore (Tamil Nadu) \& Rubber Footwear Cluster in Kottayam (Kerala)

P. Mohanan Pillai

CDS, 2001, pp 158, Paperback, Rs. 175/\$18

Poverty, Unemployment and Development Policy : A Case Study of Selected Issues With Reference to Kerala

United Nations, 2000 (reprint), pp 235

(available for sale in India only), Rs. 275

Land Relations and Agrarian Development in India: A Comparative Historical Study of Regional Variations

Sakti Padhi

CDS,1999. pp 335, Hardcover, Rs. 425/\$48

Agrarian Transition Under Colonialism: Study of A Semi Arid Region of Andhra, C.1860-1900

GN Rao

CDS,1999. pp 133, Paperback, Rs. 170/ \$19

Property Rights, Resource Management \& Governance: Crafting An Institutional Framework for Global Marine Fisheries John Kurien

CDS \& SIFFS, 1998. pp 56, Paperback, Rs. 50/ \$10 
Health, Inequality and Welfare Economics

Amartya Sen

CDS. 1996. pp 26, Paperback, Rs. 70/ \$ 10

Industrialisation in Kerala: Status of Current Research and Future Issues

P Mohanan Pillai \& N Shanta

CDS. 1997. pp 74, Paperback, Rs. 110/ \$ 12

CDS M.Phil Theses (1990/91-1993/94): A Review Vol.II

T T Sreekumar

CDS. 1996. pp 99, Paperback, Rs. 120/\$ 14

Trends In Agricultural Wages in Kerala 1960-1990

A A Baby

CDS. 1996. pp 83, Paperback, Rs. 105/ \$ 12

CDS M.Phil Theses (1975/76-1989/90): A Review Vol.1

G N Rao

CDS. 1996. pp 162, Paperback, Rs. 155/ \$ 18

Growth of Education in Andhra - A Long Run View

C Upendranath

CDS. 1994. pp 158, Paperback, Rs. 135/ \$ 15

Growth of Market Towns in Andhra: A Study of the Rayalseema Region C 1900-C.1945

Namerta

CDS. 1994. pp 186, Paperback, Rs.125/ \$ 14

Floods and Flood Control Policies: an Analysis With Reference to the Mahanadi Delta in Orissa

Sadhana Satapathy

CDS. 1993 pp 98, Paperback, Rs. 110/\$ 12

Growth of Firms in Indian Manufacturing Industry

N Shanta

CDS. 1994. pp 228, Hardcover, Rs. 250/ \$ 28

Demographic Transition in Kerala in the 1980s

K C Zachariah, S Irudaya Rajan, P S Sarma, K Navaneetham, P S Gopinathan Nair \& U S Mishra,

CDS. 1999 (2 ${ }^{\text {nd }}$ Edition) pp 305, Paperback, Rs.250/ \$ 28 
Impact of External Transfers on the Regional Economy of Kerala P R Gopinathan Nair \& P Mohanan Pillai

CDS 1994. pp 36, Paperback, Rs.30/ \$ 10

Urban Process in Kerala 1900-1981

T T Sreekumar

CDS. 1993. pp 86, Paperback, Rs.100/ \$ 11

Peasant Economy and The Sugar Cooperative: A Study Of The Aska Region in Orissa

Keshabananda Das

CDS. 1993. pp 146, Paperback, Rs.140/ \$ 16

Industrial Concentration and Economic Behaviour: Case Study of Indian Tyre Industry

Sunil Mani

CDS. 1993. pp 311, Hardcover, Rs. 300/ \$ 34

Limits To Kerala Model of Development: An Analysis of Fiscal Crisis and Its Implications.

K K George

CDS. 1999 ( $2^{\text {nd }}$ edition) pp 128, Paperback, Rs. 160/ \$ 18

Indian Industrialization: Structure and Policy Issues. (No Stock) Arun Ghosh, K K Subrahmanian, Mridul Eapen \& Haseeb A Drabu (EDs).

OUP. 1992. pp 364, Hardcover, Rs.350/ \$ 40

Rural Household Savings and Investment: A Study of Some Selected Villages

P G K Panikar, P Mohanan Pillai \& T K Sundari

CDS. 1992. pp 144, Paperback, Rs. 50/ \$ 10

International Environment, Multinational Corporations and Drug Policy

P G K Panikar, P Mohanan Pillai \& T K Sundari

CDS. 1992. pp 77, Paperback, Rs.40/ \$ 10

Trends in Private Corporate Savings

N Shanta

CDS. 1991. pp 90, Paperback, Rs. 25/ \$ 10 
Coconut Development in Kerala: Ex-post Evaluation

D Narayana, K N Nair, P Sivanandan, N Shanta and

G N Rao

CDS. 1991. pp 139, Paperback, Rs.40/ \$ 10

Caste and The Agrarian Structure

T K Sundari

Oxford \& IBH. 1991. pp 175, Paperback, Rs.125/ \$ 14

Livestock Economy of Kerala

P S George and K N Nair

CDS. 1990. pp 189, Hardcover, Rs. 95/ \$ 10

The Pepper Economy of India (No Stock)

P S George, K N Nair and K Pushpangadan

Oxford \& IBH. 1989. pp 88, Paperback, Rs. 65/ \$ 10

The Motor Vehicle Industry in India

(Growth within a Regulatory Environment)

D Narayana

Oxford \& IBH. 1989. pp 99, Paperback, Rs. 75/ \$ 10

Ecology or Economics in Cardamom Development (No Stock)

K N Nair, D Narayana and P Sivanandan

Oxford \& IBH. 1989. pp 99, Paperback, Rs. 75/ \$ 10

Land Transfers and Family Partitioning

D Rajasekhar

Oxford and IBH. 1988. pp 90, Hardcover, Rs. 66/ \$ 10

Essays in Federal Financial Relations

I S Gulati and K K George

Oxford and IBH. 1988. pp 172, Hardcover, Rs. 82/ \$ 10

Bovine Economy in India

A Vaidyanathan

Oxford \& IBH. 1988. pp 209, Hardcover, Rs. 96/ \$ 11

Health Status of Kerala

P G K Panikar and C R Soman

CDS. 1984. pp 159, Hardcover, Rs.100/ \$ 11 \& Paperback, Rs. 75/ \$ 10 
This work is licensed under a

Creative Commons

Attribution - NonCommercial - NoDerivs 3.0 Licence.

To view a copy of the licence please see:

http://creativecommons.org/licenses/by-nc-nd/3.0/ 